\title{
Charakterystyka środowisk depozycyjnych Jeziora Czechowskiego i jego otoczenia
}

\author{
Characteristics of depositional environments of Czechowskie Lake basin and its vicinity
}

\begin{abstract}
Jarosław Kordowski ${ }^{1}$, Mirosław Błaszkiewicz ${ }^{1}$, Mateusz Kramkowski ${ }^{1}$, Michał Słowiński ${ }^{1,2}$, Sebastian Tyszkowski ${ }^{1}$, Achim Brauer ${ }^{2}$, Dariusz Brykała ${ }^{1}$, Piotr Gierszewski ${ }^{1}$, Piotr Lamparski ${ }^{1}$, Monika Lutyńska ${ }^{3}$, Joanna Mirosław-Grabowska ${ }^{4}$, Agnieszka M. Noryśkiewicz ${ }^{5}$, Milena Obremska ${ }^{4}$, Florian Ott², Sabine Wulf², Izabela Zawiska ${ }^{2,6}$
\end{abstract}

${ }^{1}$ Instytut Geografii i Przestrzennego Zagospodarowania, Polska Akademia Nauk, Toruń, jarek@geopan.torun.pl

${ }^{2}$ GeoForschungsZentrum, Poczdam, Niemcy

${ }^{3}$ Instytut Geoekologii i Geoinformacji, Uniwersytet im. Adama Mickiewicza w Poznaniu

${ }^{4}$ Instytut Nauk Geologicznych, Polska Akademia Nauk, Warszawa

${ }^{5}$ Instytut Archeologii, Uniwersytet Mikotaja Kopernika, Toruń

${ }^{6}$ Instytut Geografii i Przestrzennego Zagospodarowania, Polska Akademia Nauk, Warszawa

Zarys treści: W artykule przedstawiono przegląd badań nad morfogenezą misy jeziornej Jeziora Czechowskiego na Pojezierzu Starogardzkim. W dostępnych odsłonięciach, wkopach i wierceniach o nienaruszonej strukturze przeprowadzono analizę sedymentologiczną osadów glacjofluwialnych, glacjolimnicznych, limnicznych i stokowych. Wyniki tej analizy uzupełniono rezultatami kartowania geologicznego i geomorfologicznego. W efekcie przeprowadzonych prac stwierdzono, że misa jeziora założona jest w głębokiej rynnie subglacjalnej, która do początku allerødu zakonserwowana była bryłami martwego lodu. Ich wytopienie doprowadziło do powstania zróżnicowanej morfologii dna rynny. W najgłębszych miejscach, dzięki ograniczonej miksji, były warunki do zachowania rocznej laminacji osadów dennych. Sedymentacja osadów glacjofluwialnych w otoczeniu rynny była bardzo zróżnicowana i w wielu miejscach wskazuje na warunki przepływu nadkrytycznego. W przypowierzchniowej warstwie osadów sandrowych stwierdzono ślady zapisu procesów mrozowych (gleby mrozowe) oraz wytrącenia węglanowe wskazujące na występowanie warunków peryglacjalnych po zaprzestaniu przepływu proglacjalnego. Osady limniczne są również zróżnicowane w zależności od cech morfometrycznych basenu sedymentacyjnego, a przede wszystkim od głębokości ich depozycji. Osady stokowe pochodzą w większości z ostatnich dwustu lat, a ich depozycja nastąpiła wskutek działalności gospodarczej człowieka.

Słowa kluczowe: martwy lód, misa jeziorna, analiza sedymentologiczna, Pojezierze Starogardzkie

\begin{abstract}
The paper aims to review the investigations on the genesis of the Czechowskie Lake basin (Starogard Lakeland, north-central Poland). The sedimentological analysis of the glaciofluvial, glaciolimnic, limnic and colluvial deposits have been conducted in the outcrops, pits and boreholes with undisturbed cores. They were supplemented by the results of the geological and geomorphological mapping. Summing up the investigations it can be stated that the lake basin developed within a deep subglacial channel which was preserved by the dead ice blocks till the onset of the Allerød. Their melting led to the emergence of a morphologically diversified lake basin. The conditions in its deepest parts, due to hampered mixing and wave action, favoured the preservation of the annually laminated sediments. The glaciofluvial deposition in the vicinity of the lake was diverse and in many places it indicates the supercritical condition of the water flow. Within the near-surface layer of outwash deposits were recognized the traces of the periglacial processes and calcareous precipitates which indicate short glaciolimnic periods or breaks in sedimentation. The limnic sediments are also diversified and dependent on the morphometric features of the sedimentary basin, mostly the depth of the deposition. Colluvial deposits have originated mostly in the last 200 years as a consequence of the transient deforestation of the surrounding area.
\end{abstract}

Key words: dead-ice, lake basin, sedimentological analysis, Starogard Lakeland 


\section{Wstęp}

Jezioro Czechowskie znajduje się w północnej części Borów Tucholskich przy granicy z Pojezierzem Starogardzkim. Obszar ten pokryty był ostatnim zlodowaceniem (ryc. 1B). W czasie recesji lądolodu na linię postoju fazy pomorskiej powstała strefa marginalna, na której swój początek mają rozległe równiny sandrowe Borów Tucholskich. Strefa ta lokalnie zaznaczona jest krawędzią sedymentacyjną kontaktu lodowego (Błaszkiewicz 2005a, b) (ryc. 1A). Aktualny stan wiedzy na temat rekonstrukcji dynamiki lądolodu w czasie fazy pomorskiej wskazuje na dłuższą stagnację jego krawędzi w tym rejonie (Błaszkiewicz 2005). Ze względu na brak osadów organicznych poprzedzających bezpośrednio fazę pomorską w tym rejonie, za Kozarskim (1995) i Marksem (2002) przyjęto, że przypada ona na okres między 16,2 ka BP (Kozarski 1995) a 15,2 ka BP (Marks 2002).
Przedpole fazy pomorskiej stanowią rozległe pola sandrowe zbudowane $\mathrm{z}$ piasków i żwirów o miąższości do $30 \mathrm{~m}$. Liczne są również rynny subglacjalne oraz pola wydmowe powstałe w przeważającej części w młodszym dryasie (Błaszkiewicz i in. 2006, Kaiser i in. 2010). Zaplecze fazy pomorskiej zdominowane jest przez falistą wysoczyznę morenową z dolinami rzecznymi założonymi w rynnach subglacjalnych. Powierzchnie wysoczyzn morenowych urozmaicone są w wielu miejscach przez formy wytopiskowo-kemowe, wskazujące na zmienny przestrzennie, arealny charakter zaniku lądolodu. Istnieją dowody na wkroczenie wieloletniej zmarzliny na obszary uwalniane spod lądolodu. Opierają się one na obecności termicznych szczelin kontrakcyjnych ukierunkowanych wytopisk na sandrach i glebach peryglacjalnych (Błaszkiewicz 2011, van Loon i in. 2012).

W obrębie profundalu misy Jeziora Czechowskiego rozpoznano rocznie laminowane osady jeziorne (Błasz-

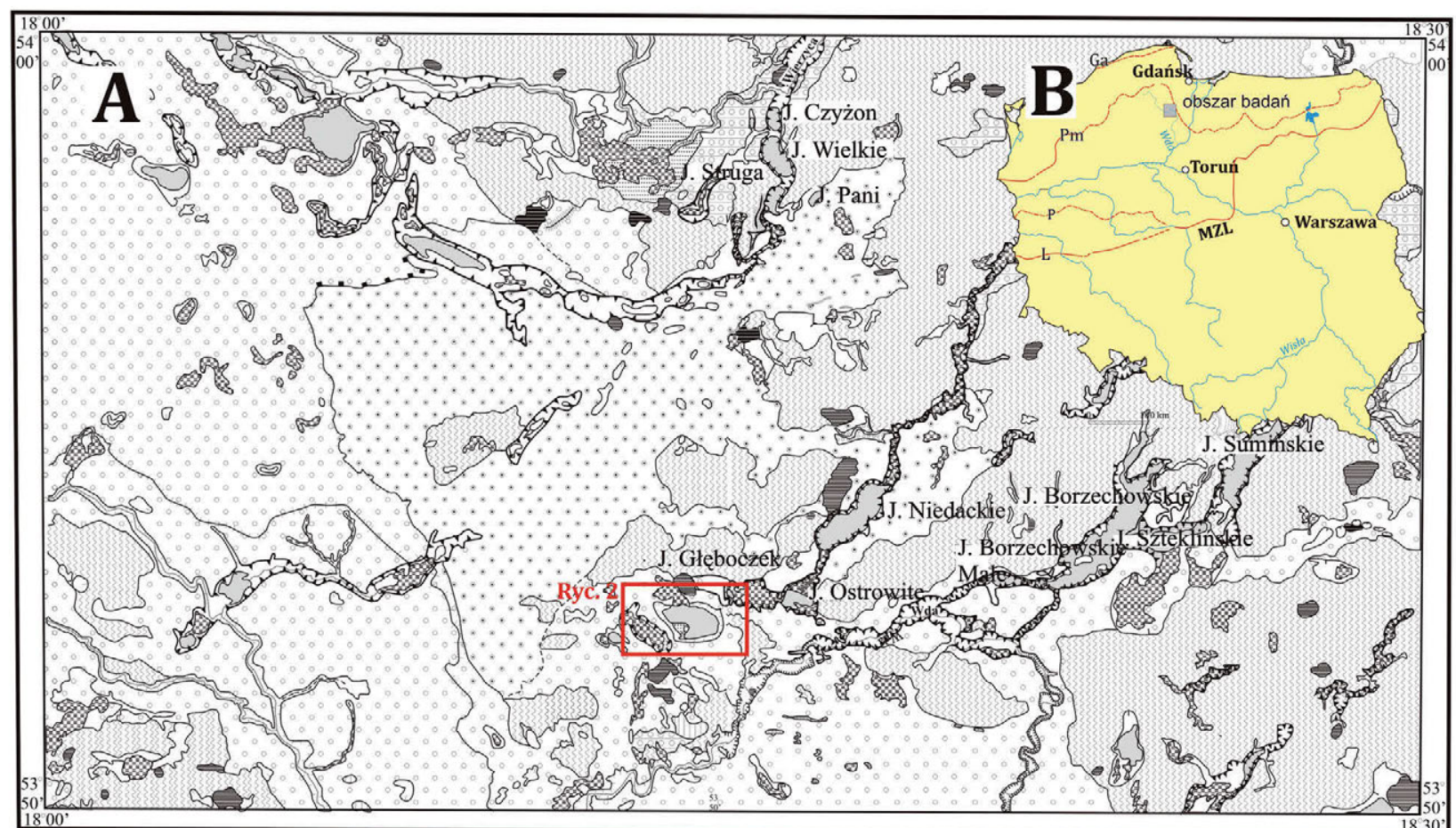
1

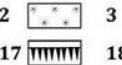
$4 \square 5$

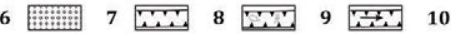
11
12
13
14 15

Ryc. 1. A - szkic geomorfologiczny zachodniej i środkowej części Pojezierza Starogardzkiego, arkusze Stara Kiszewa i Zblewo szczegółowej mapy geologicznej Polski w skali 1:50 000 (Błaszkiewicz 2005 b, c, 2006), B - lokalizacja obszaru badań na tle maksymalnego zasięgu lądolodu (wg Kozarskiego, 1995) (L - faza leszczyńska, P - faza poznańska, Pm - faza pomorska, Ga - faza gardzieńska, MZL - maksymalny zasięg lądolodu)

1 - wysoczyzny morenowe płaskie, 2 - wysoczyzny morenowe faliste, 3 - wyższy poziom sandrowy, 4 - niższy poziom sandrowy, 5 - ozy, 6 - kemy, 7 - terasy kemowe, 8 - rynny subglacjalne, 9 - wyniosłości i progi w dnach rynien, 10 - doliny wód roztopowych, 11 - zagłębienia po martwym lodzie,

12 - drumliny, 13 - wydmy, 14 - równiny piasków przewianych, 15 - dna dolin rzecznych, 16 - dolinki, parowy, młode rozcięcia erozyjne lub dolinki w ogólności, nierozdzielone, 17 - dolinki denudacyjne, 18 - długie stoki, 19 - równiny jeziorne, 20 - terasy jeziorne, 21 - równiny torfowe

Fig. 1. A - geomorphology of the western and central parts of the Starogard Lakeland, map sheets Stara Kiszewa and Zblewo of the Detailed geological map of Poland at the scale 1:50 000 (Błaszkiewicz 2005 b, c, 2006), B - location of the investigated area with the extent of the last glacial maximum (after Kozarski 1995) (L - Leszno phase, P - Poznań phase, Pm - Pomeranian phase, Ga - Gardno phase, MZL - Last Glacial Maximum

1 - flat morainic plateaus, 2 - undulating morainic plateaus, 3 - higher outwash level, 4 - lower outwash level, 5 - eskers, 6 - kames, 7 - kame terraces, 8 - subglacial channels, 9 - elevations and thresholds in subglacial channel floors, 10 - small melt water routes, 11 - kettle holes, 12 - drumlins, 13 dunes, 14 - eolian sand covers, 15 , valley floors, 16 - small gullies and young incisions, not subdivided, 17 - denudation niches, 18 - long slopes, 19 - lake plains, 20 - lake terraces, 21 - peatlands 
kiewicz 2005a). Zapisana jest w nich w sposób ciągły historia klimatu regionu Pojezierza Starogardzkiego trwająca od przełomu bøllingu i starszego dryasu po czasy współczesne. Początek sedymentacji jeziornej na Pojezierzu Starogardzkim był asynchroniczny. Większość jezior pochodzi z bøllingu i starszego dryasu, ale znane są również jeziora starsze uformowane przed bøllingiem. Ostatnia powstała preborealna generacja jezior (Błaszkiewicz 2005a). Świadczy to o zróżnicowanym tempie wytapiania pogrzebanych brył martwego lodu, a także o lokalnej przetrwałości wieloletniej zmarzliny do początku holocenu (Błaszkiewicz 2011).

\section{Cele i obszar badawczy}

Celem przeprowadzonych badań było: a) ustalenie genezy misy jeziornej wraz z określeniem początku sedymentacji jeziornej, b) rekonstrukcja zmian morfologii misy jeziornej w późnym glacjale i holocenie oraz c) ustalenie genezy form rzeźby w otoczeniu jeziora.

Jezioro Czechowskie położone jest w dorzeczu Wdy, która jest lewobrzeżnym dopływem dolnej Wisły. Powierzchnia zlewni strugi odwadniającej Jezioro Czechowskie wynosi $6,27 \mathrm{~km}^{2}$. System hydrograficzny badanej zlewni tworzą dwa jeziora (Głęboczek i Czechowskie) połączone strugą o całkowitej długości $6,3 \mathrm{~km}$. Północny fragment działu wodnego zlewni jest jednocześnie działem wodnym oddzielającym dorzecza Wdy i Wierzycy.

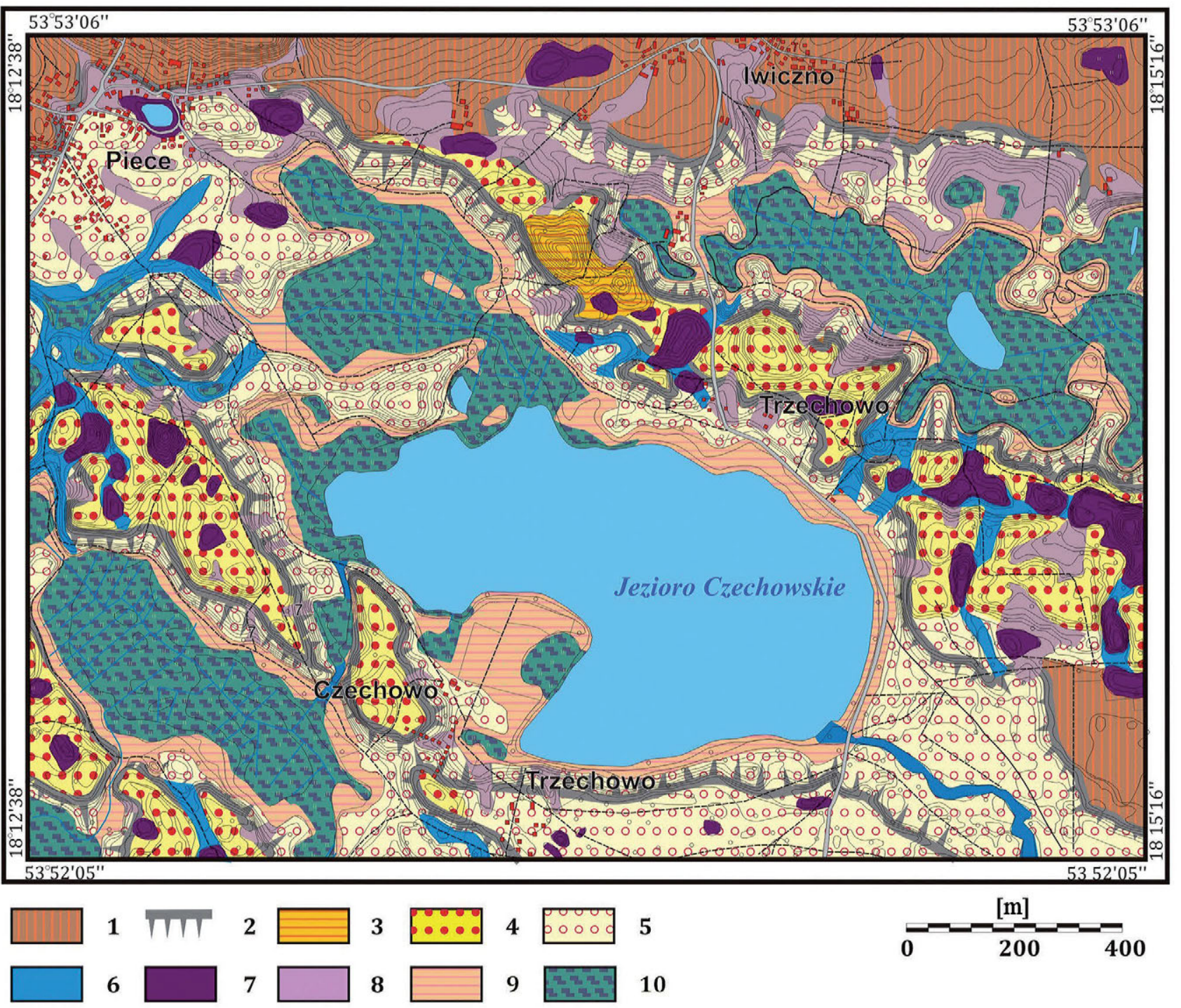

Ryc. 2. Szkic geomorfologiczny bezpośredniego otoczenia Jeziora Czechowskiego

1 - wysoczyzna morenowa, 2 - krawędzie rynien subglacjalnych (w części reprodukowane w osadach glacjofluwialnych), 3 - kemy, 4 - wyższy poziom sandrowy, 5 - niższy poziom sandrowy, 6 - młode wcięcia erozyjne, 7 - wytopiska, 8 - terasa jeziorna (częściowo zakryta osadami stokowymi), 9 - nisze erozyjno-denudacyjne, 10 - równiny biogeniczne

Fig. 2. Geomorphology of the vicinity of Czechowskie Lake

1 - morainic plateau, 2 - edges of subglacial channels (partially reproduced in the glacifluvial sediments), 3 - kames, 4 - higher outwash level, 5 - lower outwash level, 6 - young erosional incisions, 7 - kettle holes, 8 - lake terrace (partially covered by colluvium), 9 - erosion and denudation niches, 10 - biogenic plains 

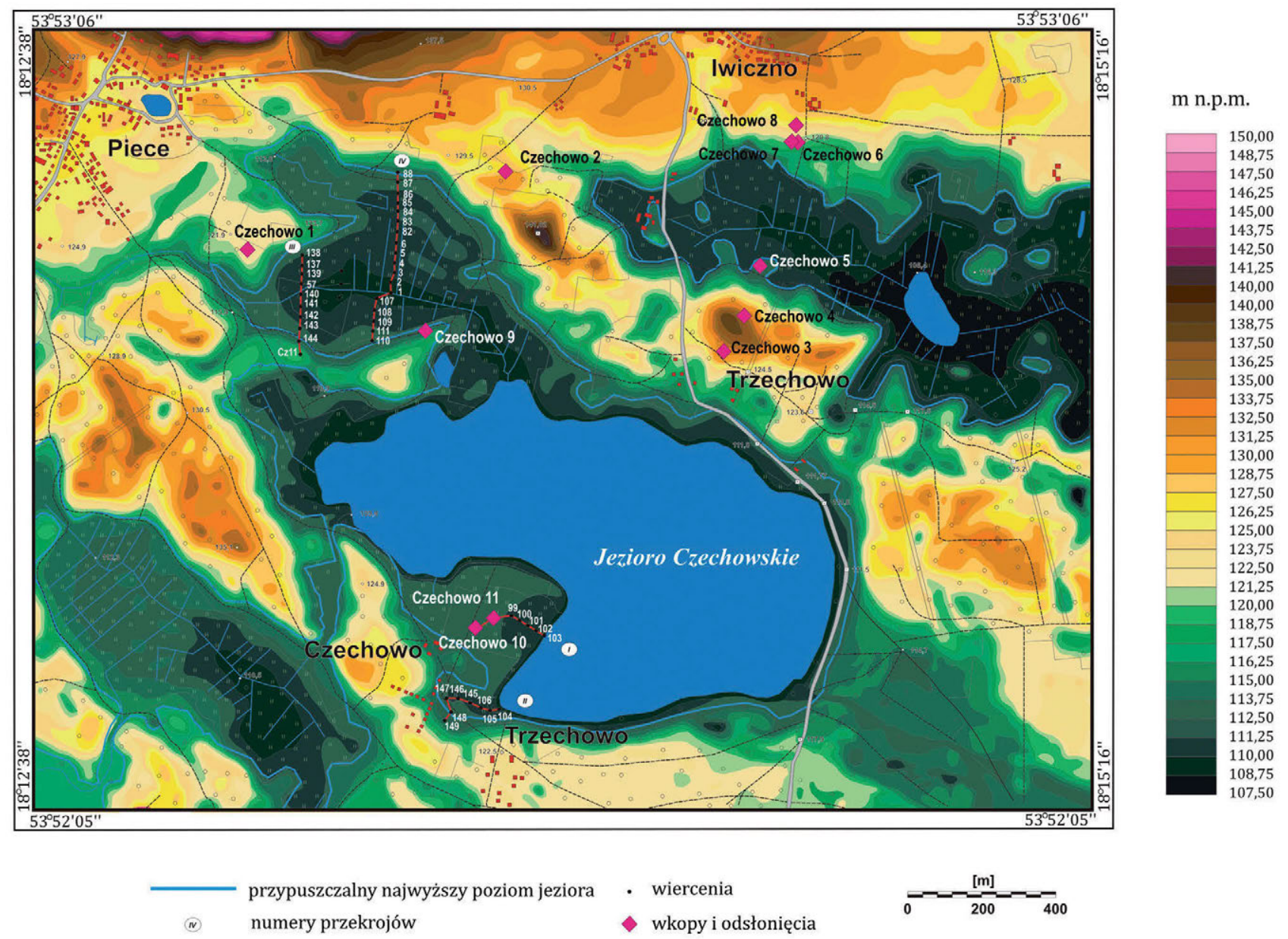

Ryc. 3. Lokalizacja wierceń, wkopów i odsłonięć omawianych w tekście w otoczeniu Jeziora Czechowskiego

Fig. 3. Location of boreholes, pits and outcrops discussed in the text in the vicinity of Czechowskie Lake

Powierzchnia Jeziora Czechowskiego wynosi 76,6 ha, a wysokość aktualnego zwierciadła wody 109,9 m n.p.m. Jezioro to ma maksymalną głębokość $32 \mathrm{~m}$, przy przeciętnej wartości 9,59 m. Objętość wody zgromadzonej w jeziorze osiagga $7350000 \mathrm{~m}^{3}$. Misa jeziorna zajmuje najgłębsze części rynny subglacjalnej powstałej w czasie recesji lądolodu na linię moren fazy pomorskiej (ryc. 2, 3). W najszerszym miejscu rynna ta ma szerokość około $1 \mathrm{~km}$. Maksymalna jej głębokość, licząc od górnych krawędzi zboczy do spągu osadów limnicznych w dnie rynny, wynosi prawie $70 \mathrm{~m}$. W rynnie stwierdzono liczne progi zbudowane $\mathrm{z}$ osadów glacjofluwialnych. Jej otoczenie stanowią dwa poziomy sandrowe, które powstały synchronicznie. Ich zróżnicowanie wysokościowe wynika z obniżenia niższego poziomu podczas wytapiania brył lodu, na jakich był akumulowany. Bardziej na północ, w okolicy Pieców i Iwiczna, dominuje równina morenowa z rozproszonymi wzgórzami kemów (ryc. 2). Powszechnie występują tu kotły wytopiskowe. Mają one bardzo zmienne rozmiary, dodatkowo w obrębie większych form występują formy mniejsze, dając bardzo zróżnicowaną morfologicznie rzeźbę terenu.

\section{Zakres prac}

W zlewni Jeziora Czechowskiego przeprowadzono reambulację kartowania geologicznego i geomorfologicznego wykonanego tu w trakcie realizacji arkusza Stara Kiszewa szczegółowej mapy geologicznej Polski w skali 1:50 000 (Błaszkiewicz 2005b, c). W celu rekonstrukcji pierwotnego kształtu misy jeziornej przeprowadzono serię wierceń (ryc. 3, 4), przeważnie za pomocą ręcznej sondy typu Instorf, uzupełnionej w kluczowych miejscach sondowaniami sondą tłokową typu Livingstone'a w modyfikacji Więckowskiego. W ten sposób uzyskano ponad 160 profilów osadów limnicznych i utworów telmatycznych (ryc. 4). W osadach glacjolimnicznych i glacjofluwialnych wykonano 13 wkopów i odsłonięć. W osadach stokowych, za pomocą sondy typu RKS, wykonano 11 wierceń z poborem rdzeni o nienaruszonej strukturze.

Odsłonięcia i rdzenie o niezaburzonym profilu analizowane były pod względem struktur sedymentacyjnych, uziarnienia, zawartości materii organicznej i węglanów. Próbki do analiz sitowych (średnice oczek 0,$1 ; 0,125 ; 0,18$; 0,$25 ; 0,315 ; 0,355 ; 0,45 ; 0,5 ; 0,63 ; 0,71 ; 0,8 ; 0,9 ; 1 ; 1,25$; $1,4 ; 2 ; 2,5 ; 3,55 ; 4 ; 5 ; 6,3 ; 7,1 ; 8 \mathrm{~mm})$ pobierano co $5 \mathrm{~cm}$. Frakcję mułkowo-ilastą mierzono na laserowym analizatorze cząstek Analysette 22 Economy. Frakcje między 0,1 


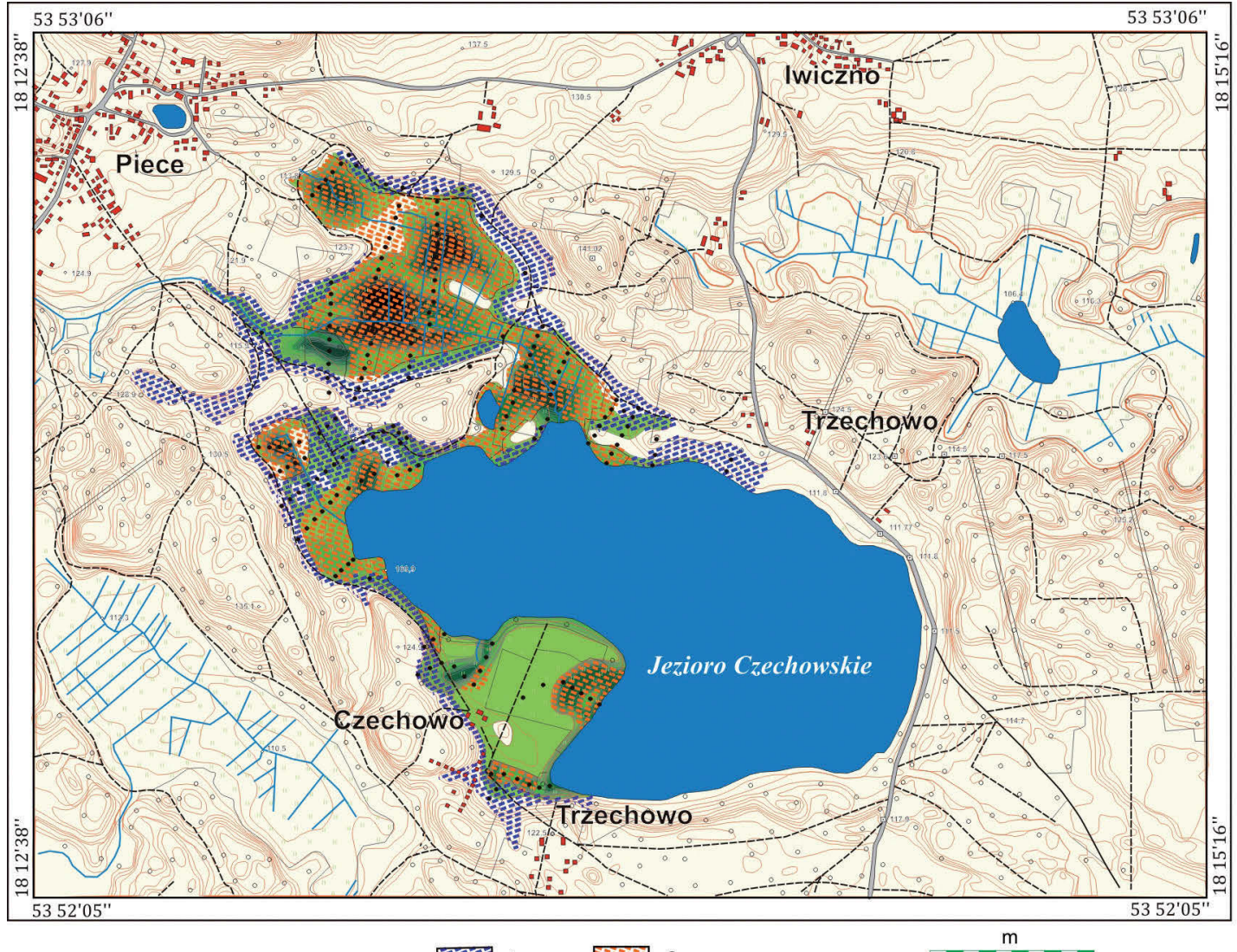

miażzzość osadów limnicznych, $m$

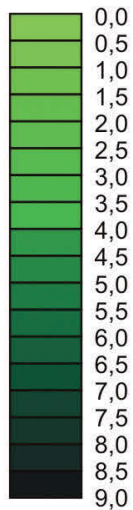

器琵㻎

2

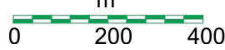

Ryc. 4. Mapa miąższości osadów limnicznych w otoczeniu Jeziora Czechowskiego

1 - osady limniczne pod pokrywą osadów stokowych, 2 - osady limniczne pod pokrywą torfów

Fig. 4. Thickness of the limnic sediments in the vicinity of Czechowskie Lake

1 - limnic sediments under colluvial cover, 2 - limnic sediments under peat cover

a $8 \mathrm{~mm}$ analizowano sitowo. Frakcje powyżej $8 \mathrm{~mm}$ mierzono ręcznie. W klasyfikacji uziarnienia posługiwano się normą PIG (Instrukcja... 2004), z następującymi przedziałami uziarnienia: ił koloidalny do $1 \mu \mathrm{m}$, ił drobnoziarnisty 1-5 $\mu \mathrm{m}$, ił gruboziarnisty 5-10 $\mu \mathrm{m}$, mułek ilasty $10-50$ $\mu \mathrm{m}$, mułek piaszczysty $50-100 \mu \mathrm{m}$, piasek drobnoziarnisty 0,1-0,25 mm, piasek średnioziarnisty $0,25-0,5 \mathrm{~mm}$, piasek gruboziarnisty $0,5-1 \mathrm{~mm}$, piasek bardzo gruboziarnisty 1-2 mm, żwir drobnoziarnisty 2-5 mm, żwir średnioziarnisty $5-10 \mathrm{~mm}$, żwir gruboziarnisty powyżej $10 \mathrm{~mm}$.

Uziarnienie osadów scharakteryzowano według wskaźników Folka i Warda (1957). Analizę zawartości węglanów przeprowadzono metodą gazową Scheiblera. Analizy strat na prażeniu prowadzono przez wyżarzanie próbek w temperaturze $550^{\circ} \mathrm{C}$ przez 4 godziny w piecu muflowym.

Badania w wierceniach i wkopach ważniejszych z punktu rekonstrukcji ewolucji jeziora uzupełnione zostały analizami palinologicznymi, datowaniami radiowęglowymi, izotopowymi $\left({ }^{16} \mathrm{O} /{ }^{18} \mathrm{O}\right)$ oraz makroszczątkowymi. Przeprowadzono także wybiórcze profilowanie niektórych części misy jeziornej za pomocą radaru GPR.

Zastosowane do opisu osadów mineralnych skróty litologiczne i strukturalne zostały zaadaptowane z publikacji Zielińskiego (1995) i Mialla (1996) z koniecznymi uzupełnieniami. Przedstawiają się one następująco: D - diamikton, $\mathrm{G}$ - żwir, $\mathrm{S}$ - piasek, $\mathrm{H}$ - próchnica, $\mathrm{C}$ - wtrącenia węglanowe, F - osady drobnoziarniste, mułki i iły, $\mathrm{d}$ - nieregularne warstwowanie zaburzone, id - deformacje wenątrzławicowe, $\mathrm{h}$ - warstwowanie horyzontalne, 1 - małokątowe warstwowanie przekątne, $\mathrm{m}$ - struktura masywna, $\mathrm{p}$ - warstwowanie przekątne płaskie, $\mathrm{w}$ - warstwowanie faliste, $\mathrm{t}$ - warstwowanie przekątne rynnowe, $\mathrm{rt}$ - rytmit heterolityczny, s - znaczna skala rozmycia, $\mathrm{Mz}$ - średnia średnica ziarna. Ze względu na brak popularnego systemu kodowego do utworów biogenicznych przedstawiono je w sposób tradycyjny, opisowy.

\section{Przegląd i charakterystyka osadów}

\section{Osady glacjofluwialne}

Osady glacjofluwialne udokumentowano we wkopach i odsłonięciach oznaczonych jako: Czechowo 1 (ryc. 5), 2 (ryc. 6), 3 (ryc. 7), 4 (ryc. 8), 5 (ryc. 9), 6 (ryc. 10), 7 (ryc. 11), 8 (ryc. 12) i 9 (ryc. 13).

Gh - żwiry warstwowane horyzontalnie. Osady te zostały stwierdzone na stanowisku Czechowo 4 (ryc. 8). Ich odmianami są litofacje GSh - żwiry i piaski warstwowane horyzontalnie i G(S)h - żwiry z domieszką piasków 
warstwowane horyzontalnie. Występują one na stanowiskach Czechowo 2 (ryc. 6) i 4 (ryc. 8). Osady te są zdominowane przez frakcję żwirową w ilości do 90\% ich masy. Domieszkę stanowią piaski o frakcji od drobno- po gruboziarnistą, które mogą osiągnąc do $50 \%$ masy osadu. Wysortowanie żwirów litofacji Gh jest skrajnie słabe. Występują w niej klasty o rozmiarach do $20 \mathrm{~cm}$, przy średniej średnicy ziarna dochodzącej do $12 \mathrm{~mm}$. Miąższość zestawów wynosi około $0,5 \mathrm{~m}$, przy czym w części zaznacza się wieloetapowość sedymentacji.

Interpretacja: litofacja Gh reprezentuje najbardziej energetyczny typ osadów obserwowany w okolicach Czechowa. Wskazuje ona na epizody gwałtownych przepływów z energią porównywalną do współczesnych wezbrań w dolinie Wisły. W czasie normalnego przepływu w dnie Wisły transportowane są bowiem klasty żwiru o rozmiarach do $10 \mathrm{~cm}$ (Babiński 1986). Ich powstaniu towarzyszyło rozmycie, być może wielometrowej miąższości, starszych osadów glacjofluwialnych i glacjolimnicznych.
SGm - masywne piaski i żwiry masywne oraz $S(G)$ m - masywne piaski z domieszką żwiru. Stwierdzone zostały na stanowiskach Czechowo 2 (ryc. 6) i 3 (ryc. 7). Są to bardzo słabo wysortowane różnofrakcyjne osady piaszczysto-żwirowe. Ich miąższość wynosi do $0,5 \mathrm{~m}$.

Interpretacja: biorąc pod uwagę kontekst geologiczny litofacji, należy przyjąć, że osady te zostały zdeponowane w efekcie osuwania po stoku lub krioturbacji w środowisku peryglacjalnym (Washburn 1979).

SGt - piaski i żwiry o warstwowaniu przekątnym rynnowym. Litofacja ta złożona jest głównie z piasków średnioziarnistych (20-30\%), gruboziarnistych (10$20 \%$ ), bardzo gruboziarnistych (5-10\%), piasku drobnoziarnistego (ok. 5\%) oraz żwiru drobnoziarnistego i średnioziarnistego (5-15\%). Wysortowanie jest słabe i bardzo słabe. Głębokość rynienek warstwowania przekątnego wynosi 20-30 cm. Kierunek paleoprądu w czasie depozycji osadów litofacji SGt na stanowisku Czechowo 9 mieścił się w sektorach wschodnich (ryc. 13).

\section{Czechowo 1-125 m n.p.m. $53^{\circ} 52$ '52,5"N; $18^{\circ} 13^{\prime} 26,7^{\prime \prime} \mathrm{E}$}

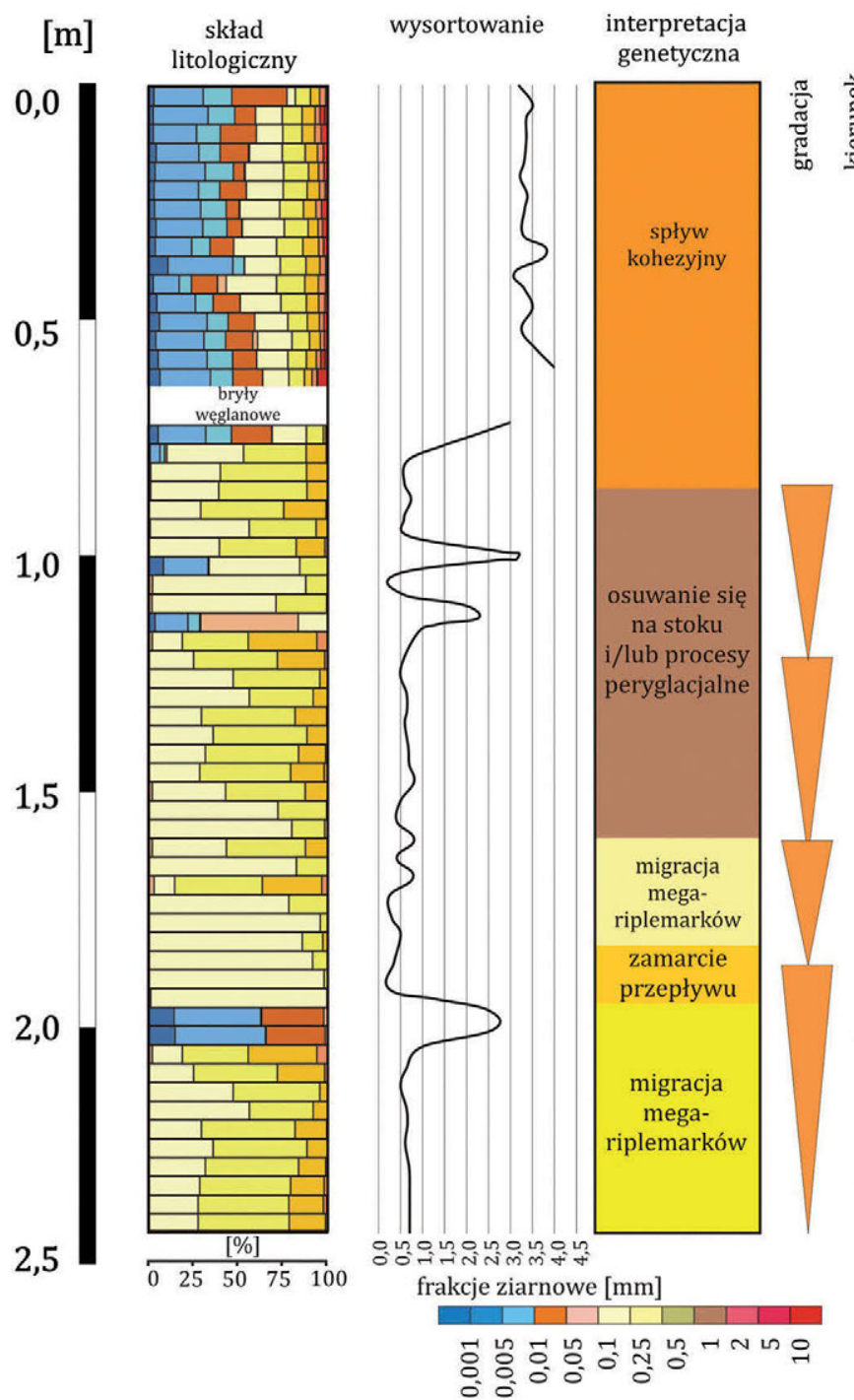

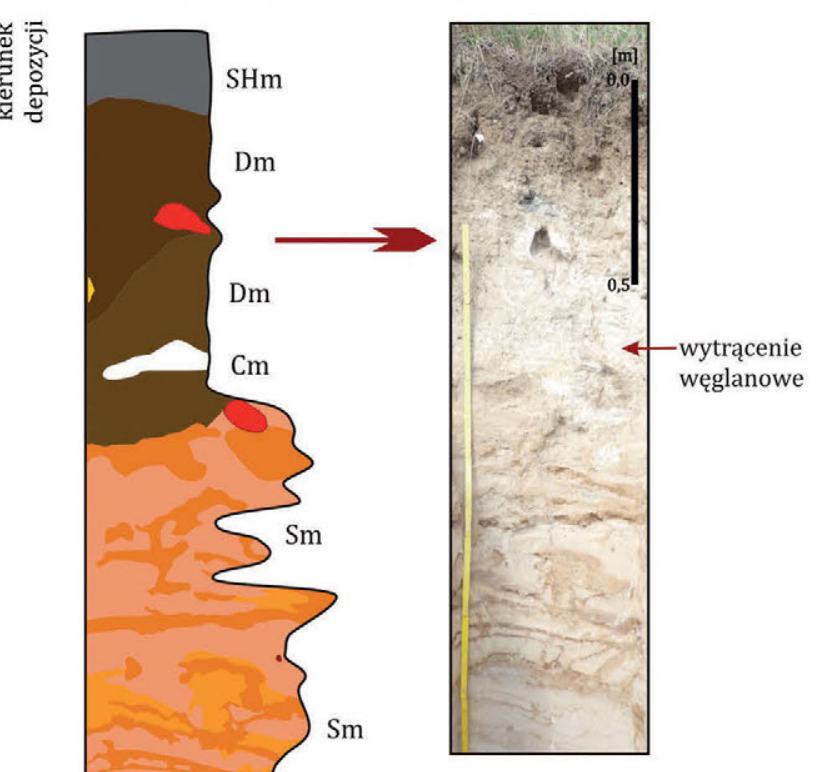

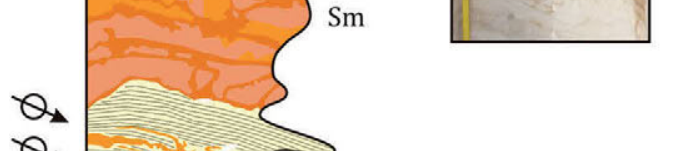

Ryc. 5. Stanowisko Czechowo 1. Osady glacjofluwialne pokryte gliną spływową

Fig. 5. Site Czechowo 1. Glacifluvial sediments capped by a flow till 
Interpretacja: charakter uziarnienia dowodzi dużej siły transportowej płynącej wody, co może wskazywać na strefę przejściową między dolnym i górnym reżimem przepływu. Warstwowanie rynnowe wiąże się generalnie z przemieszczaniem megariplemarków o krętym przebiegu linii grzbietowej (Allen 1982, Reineck, Singh 1986).

SGp - piaski i żwiry warstwowane przekątnie, płasko. Stwierdzone zostały na stanowiskach Czechowo 2 (ryc. 6), 3 (ryc. 7), 4 (ryc. 8). Litofacja ta składa się z mieszaniny piasków różnych frakcji i żwirów bardzo drobnoziarnistych oraz drobno- i średnioziarnistych w mniej więcej wyrównanych proporcjach. Są to osady o bardzo słabym wysortowaniu i o miąższości $20-40 \mathrm{~cm}$.

Interpretacja: duża zmienność cech granulometrycznych osadów litofacji SGp i obecność ziaren żwiru średnioziarnistego świadczy o dużej sile transportowej wody i migracji megariplemarków o prostych grzbietach. $\mathrm{W}$ analizowanym przypadku megariplemarki te miały między 20 a $40 \mathrm{~cm}$ wysokości.

SGp(d) - piaski i żwiry o przekątnym warstwowaniu tabularnym zaburzone synsedymentacyjnie.
Stwierdzone zostały na stanowisku Czechowo 4 (ryc. 8). Wykazują podobne cechy litologiczne jak litofacja opisana powyżej, jednak nachylenie lamin w tej litofacji jest wyższe niż kąt naturalnego zsypu. Jednocześnie w litofacji SGp(d) nie są obserwowane uskoki i fleksury.

Interpretacja: litofacja SGp(d) powstała prawdopodobnie na bryle martwego lodu silnie degradowanej w czasie jej depozycji, stąd kąt naturalnego zsypu został przekroczony w dolnej części litofacji i systematycznie zmniejszał się w czasie jej akumulacji. Piaski i żwiry o tej charakterystyce mogą powstawać również jako deformacje wewnątrzławicowe (Pisarska-Jamroży, Weckwerth 2013)

SGI - piaski i żwiry o warstwowaniu przekątnym małokatowym. Stwierdzone zostały na stanowisku Czechowo 3 (ryc. 7). Składają się z trzech cykli gradacyjnych odwróconych, o miąższości od kilkunastu centymetrów do $0,5 \mathrm{~m}$. Wykazują znaczne zróżnicowanie udziału poszczególnych frakcji ziarnowych w ogólnej masie osadu w zależności od tego, czy mamy do czynienia ze spągową czy stropową częścią litofacji. W części spągowej występują różnofrakcyjne osady piaszczyste, które stanowią do

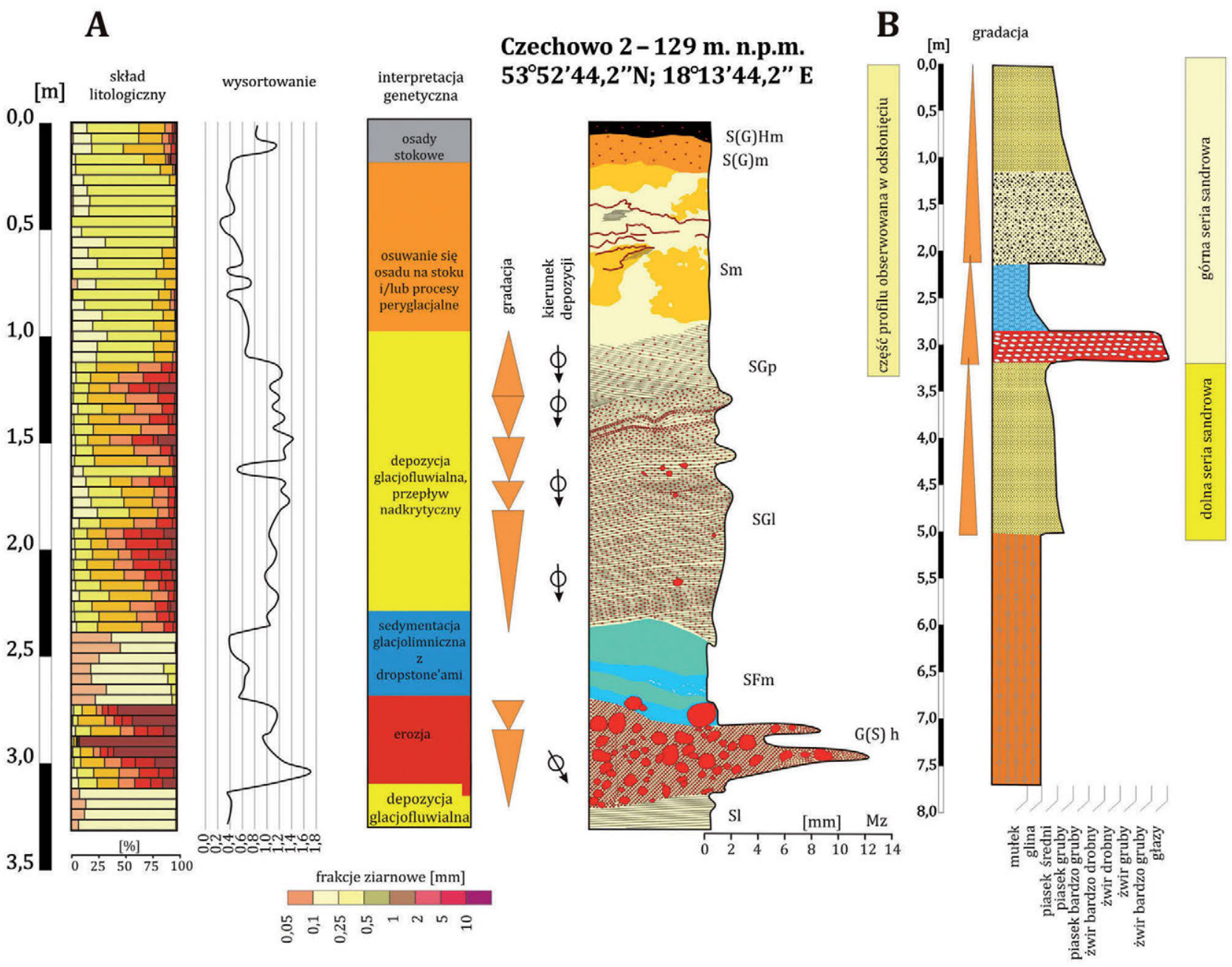

Ryc. 6. Stanowisko Czechowo 2. Osady glacjofluwialne rozdzielone epizodem sedymentacji glacjolimnicznej A - struktury wewnętrzne i uziarnienie, B - profil litologiczny wiercenia

Fig. 6. Site Czechowo 2. Glacifluvial sediments separated by a episode of the glaciolimnic sedimentation A - internal structures, B - lithological log of the borehole 
$90 \%$ masy osadu. Żwiry zajmuja w niej zaledwie $10 \%$. W stropowej części litofacji SGl udział piasków spada do około 50\% masy osadu, zaś żwiry bardzo drobnoziarniste, drobno- i średnioziarniste stanowią pozostałe $50 \%$. Wysortowanie jest bardzo słabe i pogarsza się ku stropowi litofacji. W rozproszeniu występują klasty żwirowe o średnicy kilku centymetrów. Przepływ wód odpowiedzialny za depozycję litofacji SGl następował w kierunku południowym.

Interpretacja: biorąc pod uwagę gruboziarnistość litofacji i bardzo słabe wysortowanie, należy przyjąć dużą energię środowiska depozycyjnego, związanego najprawdopodobniej z górnym reżimem przepływu lub z reżimem przejściowym pomiędzy dolnym a górnym ustrojem prądu oraz z wysoką koncentracją osadu (Allen 1982). Piaski i żwiry tej facji tworzyły niskie, rozmywalne diuny o wysokości rzędu 0,5 m i znacznej długości co najmniej kilku metrów.
S(G)h - piaski z domieszka żwiru warstwowane horyzontalnie wraz z odmianą SGh - piaskami i żwirami warstwowanymi horyzontalnie (ryc. 7, stanowisko Czechowo 3, ryc. 13, stanowisko Czechowo 9). Składają się głównie z piasku średnioziarnistego i gruboziarnistego, które stanowią razem 50-80\% masy osadu. Domieszka żwiru wynosi od kilku do blisko 40\%. Największe ziarna odpowiadają średnioziarnistemu żwirowi. Wysortowanie osadów litofacji SGh jest umiarkowane i słabe w przypadku małej zawartości żwiru, a bardzo słabe w przypadku dużej zawartości. Obserwowane były pakiety o miąższości co najmniej 1,5 m, z cyklami gradacyjnymi zarówno prostymi, jak i odwróconymi. Ich miąższość wynosiła od kilkunastu centymetrów do $1 \mathrm{~m}$.

Interpretacja: rozkłady uziarnienia cechujące się obecnością wielu frakcji piaszczystych wraz z ziarnami żwirów średnioziarnistych oraz słabe wysortowanie osadu wskazują wraz ze strukturą sedymentacyjną na dużą
A

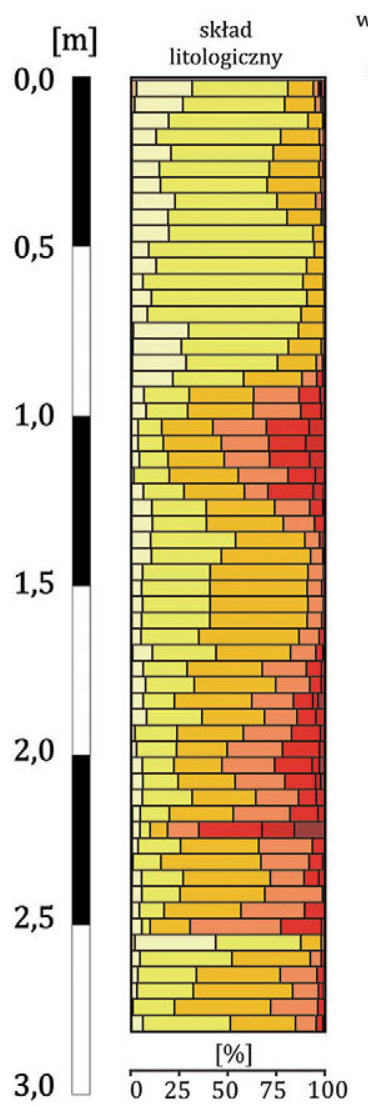

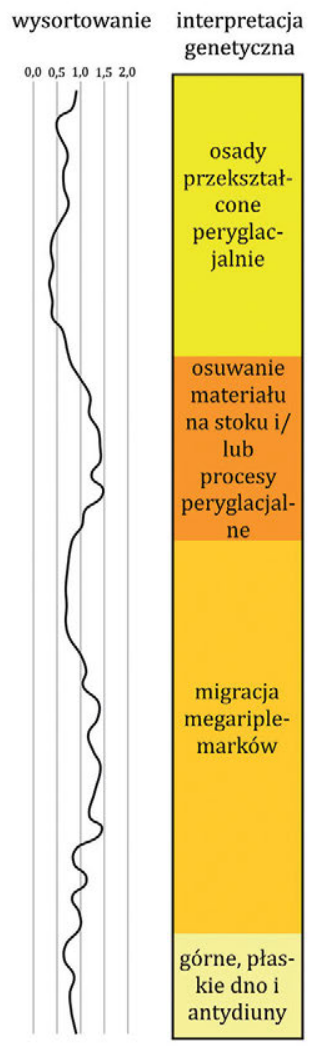

frakcje ziarnowe $[\mathrm{mm}]$ ( )

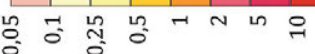

Q.

$\phi$

$\phi$
Czechowo 3 - 130 m n.p.m. $53^{\circ} 52^{\prime} 43,6^{\prime \prime} \mathrm{N} ; 1^{\circ} 14^{\prime} 23,3$ 'E
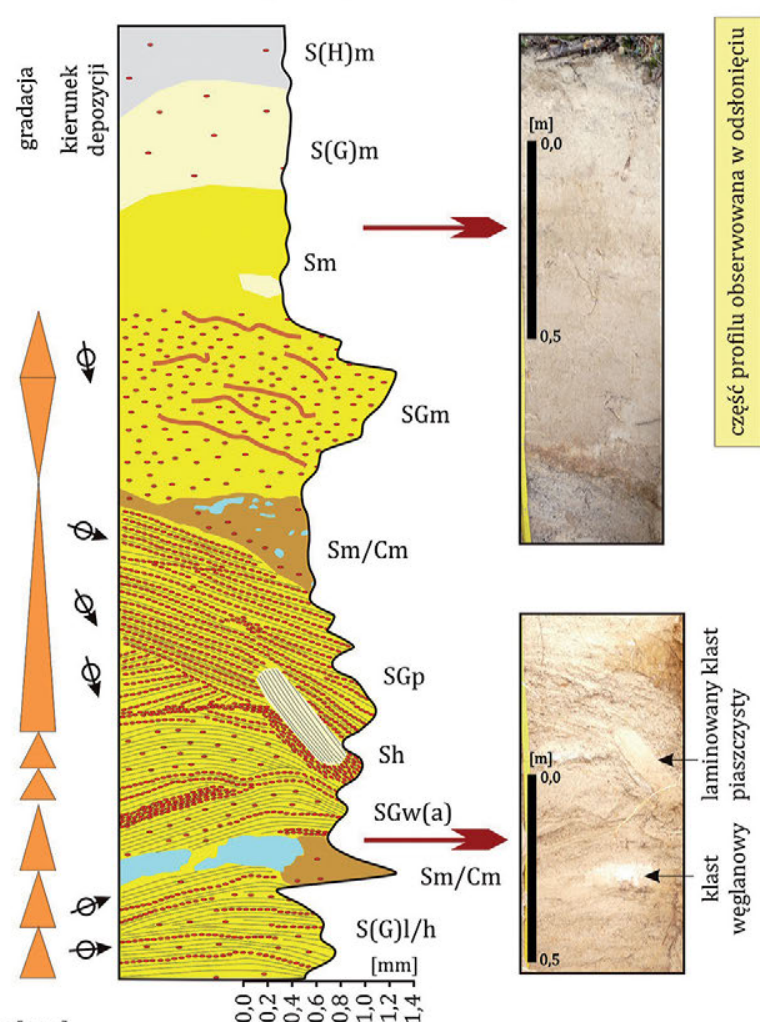

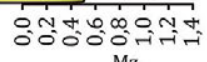

$\mathrm{Mz}$

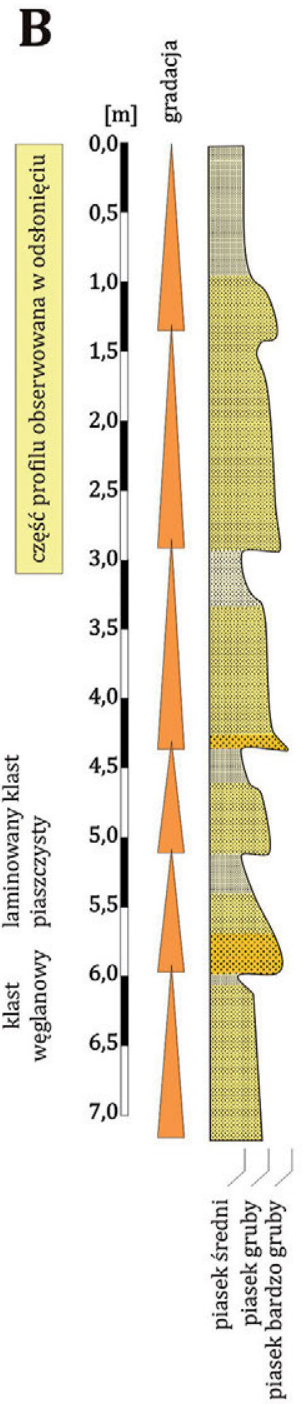

Ryc. 7. Stanowisko Czechowo 3. Osady glacjofluwialne zwieńczone osadami przekształconymi peryglacjalnie. A - struktury wewnętrzne i uziarnienie; B - profil litologiczny wiercenia

Fig. 7. Site Czechowo 3. Glacifluvial sediments capped by periglacially transformed sediments. A - internal structures; B - lithological $\log$ of the borehole 
siłę transportową wody w fazie górnego płaskiego dna (Reineck, Singh 1986).

SGw(a) - piaski i żwiry o warstwowaniu falistym, antywydmowym. Stwierdzone zostały na stanowisku Czechowo 3 (ryc. 7). Litofację tę tworzą piaski gruboi bardzogruboziarniste, których łączny udział wynosi około $80 \%$ masy osadu. Kilkanaście procent stanowi piasek drobno- i średnioziarnisty, a kilka procent to żwiry bardzo drobno- i drobnoziarniste. Całość jest bardzo słabo wysortowana. Miąższość litofacji osiąga kilkanaście centymetrów.

Interpretacja: Warstwowanie faliste powstaje w wielu środowiskach depozycyjnych (Miall 1996). Nie zawsze można je wiązać $z$ antywydmami. W przypadku symetrycznego charakteru lamin piaszczysto-żwirowych, bez przemieszczania grzbietów fali, można wnioskować o ich genezie związanej z antydiunami o stacjonarnym charakterze (Allen 1982, Cartigny i in. 2014). Antydiuny uważane są za diagnostyczne dla nadkrytycznego reżimu przepływu (Zieliński 1988). Geneza litofacji SGw(a) jest zbliżona do litofacji Sw(a).

SI - piaski o warstwowaniu przekątnym małokątowym. Osady te zostały stwierdzone na stanowisku Cze- chowo 2 (ryc. 6) i 8 (ryc. 12). Litofacja ta złożona jest z piasku drobnoziarnistego (90-95\%) i mułku piaszczystego (5-10\%). Osady te wykazują bardzo dobre wysortowanie.

Interpretacja: litofacja $\mathrm{S} 1$ związana jest z rozwojem rozmywanych i niewielkiej wysokości diun o znacznej długości, które powstają w warunkach przejściowych pomiędzy dolnym a górnym ustrojem prądu (Allen 1982).

Srt - rytmity piaszczyste. Stwierdzone zostały na stanowisku Czechowo 7 (ryc. 11). Tworzą je 2-3-centymetrowe przewarstwienia piasku średnio- i gruboziarnistego o słabym wysortowaniu, ze zmienną zawartością piasku drobnoziarnistego.

Interpretacja: litofacje Srt są prawdopodobnie śladem gwałtownego wyhamowania prądu wody i depozycji z przeciążonej zawiesiny ziarnowej (Syverson 1998). Wyhamowanie nastąpiło wskutek utraty energii grawitacyjnej w strefie zmniejszenia spadku przepływu wody.

$\mathrm{Sm} / \mathrm{Cm}$ i $\mathbf{C m}$ - piaski masywne $z$ redeponowanymi klastami węglanowymi oraz nieregularne wytrącenia węglanowe. Stwierdzone zostały na stanowiskach Czechowo 1 (ryc. 5), Czechowo 3 (ryc. 7) i Czechowo 5 (ryc. 9). Klasty węglanowe mają różną wielkość i kształt (od 1-2

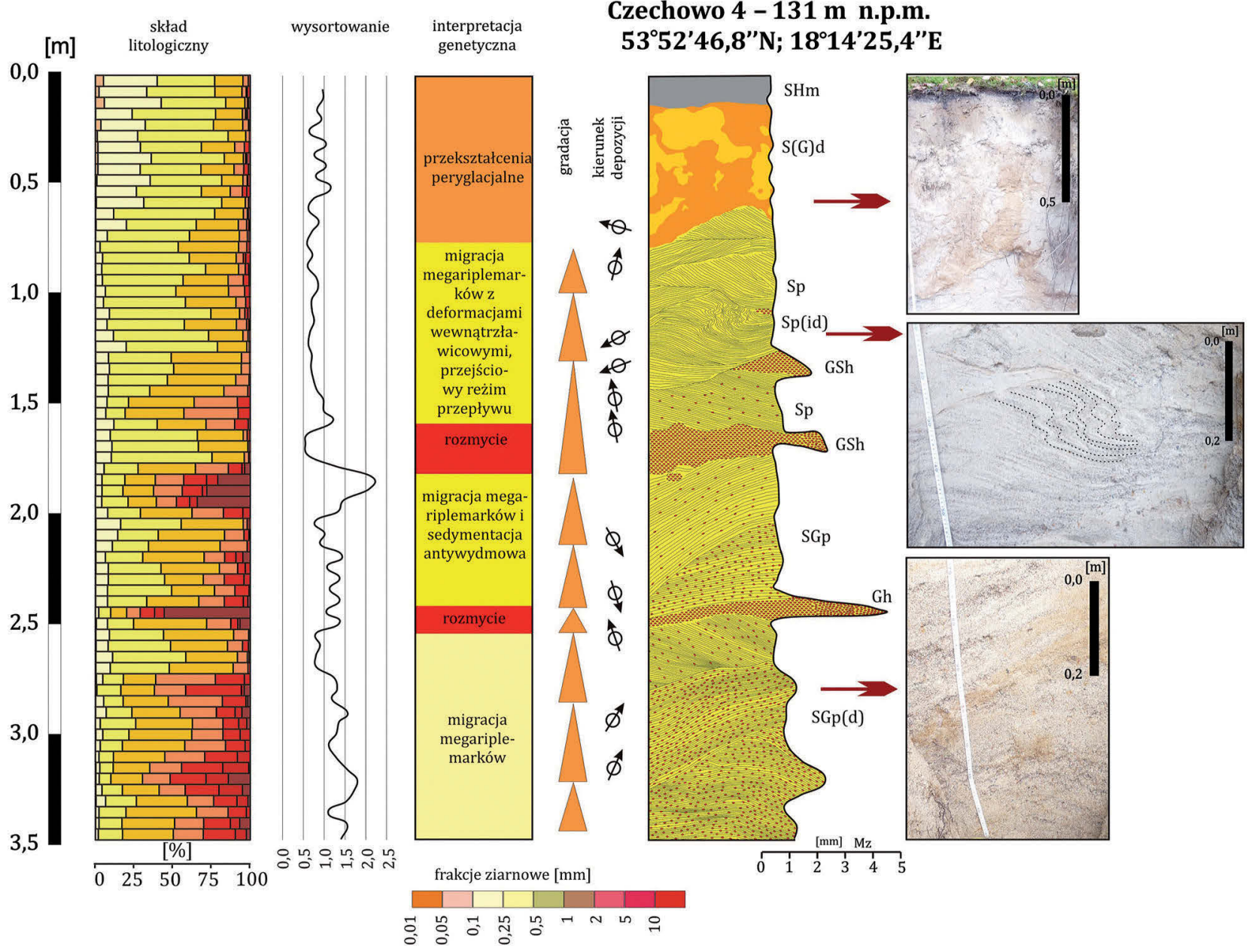

Ryc. 8. Stanowisko Czechowo 5. Osady glacjofluwialne z deformacjami wewnątrzławicowymi

Fig. 8. Site Czechowo 5. Glacifluvial sediments with intrastratal deformations 
mm do 2-3 cm), niekiedy zawierają domieszkę mułków. Nieregularne wytrącenia węglanowe $(\mathrm{Cm})$ mają miąższość do $20 \mathrm{~cm}$ i tworzą albo nieregularne soczewy oraz buły o rozmiarach poziomych do $40-50 \mathrm{~cm}$ i pionowych od kilku milimetrów do $20 \mathrm{~cm}$, albo bardzo cienkie, ciągłe warstewki w obrębie osadów glacjolimnicznych i glacjofluwialnych, liczące zaledwie kilka milimetrów (ryc. 5, 7, 9).

Interpretacja: wytrącenia węglanowe mogły powstać na rozmaite sposoby. Te występujące w postaci ciągłych, cienkich warstw mogą znaczyć epizody spadku ciśnienia wód subglacjalnych wskutek ich wydostawania się na powierzchnię (Bukowska-Jania 2003). Mogą też być efektem procesów peryglacjalnych. Nieregularne buły i soczewy były prawdopodobnie inkorporowane w materiał morenowy przemieszczający się po stoku wytapiającej się bryły lodu.

Sd - piaski warstwowane, zdeformowane. Stwierdzone zostały na stanowisku Czechowo 7 (ryc. 11). Litofacja ta zbudowana jest $\mathrm{z}$ piasku średnioziarnistego (ok. $50 \%$ ) z domieszkami piasku drobno- i gruboziarnistego (po ok. 25\%). Osady te tworzą warstwę o miąższości około $20 \mathrm{~cm}$ i są umiarkowanie wysortowane.

Interpretacja: charakter zaburzeń wskazuje na deformacje wskutek napierania kier lodowych tworzących się w obrębie zbiornika sedymentacyjnego. Zaburzenia nie są obserwowane w warstwach wyżej ani niżej leżących, co wyklucza deformację w wyniku dezintegracji brył martwego lodu lub deformację wskutek nadmiernego obciążenia osadu.

Sp - piaski warstwowane przekątnie, tabularnie. Stwierdzone zostały na stanowiskach Czechowo 1 (ryc. 5), 4 (ryc. 8), 8 (ryc. 12). W odsłonięciu Czechowo 9 litofacja ta złożona jest $\mathrm{z}$ piasków średnioziarnistych (80-90\%) z domieszką gruboziarnistych (5-10\%) i drobnoziarnistych (5-10\%). Osady te są bardzo dobrze wysortowane i były obserwowane w postaci jednolitej ławicy o miąższości przynajmniej $1 \mathrm{~m}$, z cyklem gradacyjnym prostym. Podobne charakterystyki dotyczą tej litofacji w odsłonięciach Czechowo 1 i 8, z tym że w tym ostatnim obserwowano cykle gradacyjne odwrócone (ryc. 5, 12).

Interpretacja: piaszczysta litofacja o warstwowaniu przekątnym płaskim związana jest genetycznie z migracją megariplemarków o prostych grzbietach, w warunkach dolnego reżimu przepływu wody. Wysokość akumulowanych form była różna, od 20-30 $\mathrm{cm}$ do ponad $1 \mathrm{~m}$, co odpowiada wielkością małym odsypom rzecznym. Kierunki paleoprzepływów były różne, $\mathrm{z}$ reguły mieściły się w sektorach północnych i wschodnich.

\section{Czechowo 5-112 m n.p.m.}

$53^{\circ} 52^{\prime} 49,7^{\prime \prime} \mathrm{N} ; 18^{\circ} 14^{\prime \prime} 32,7^{\prime \prime} \mathrm{E}$

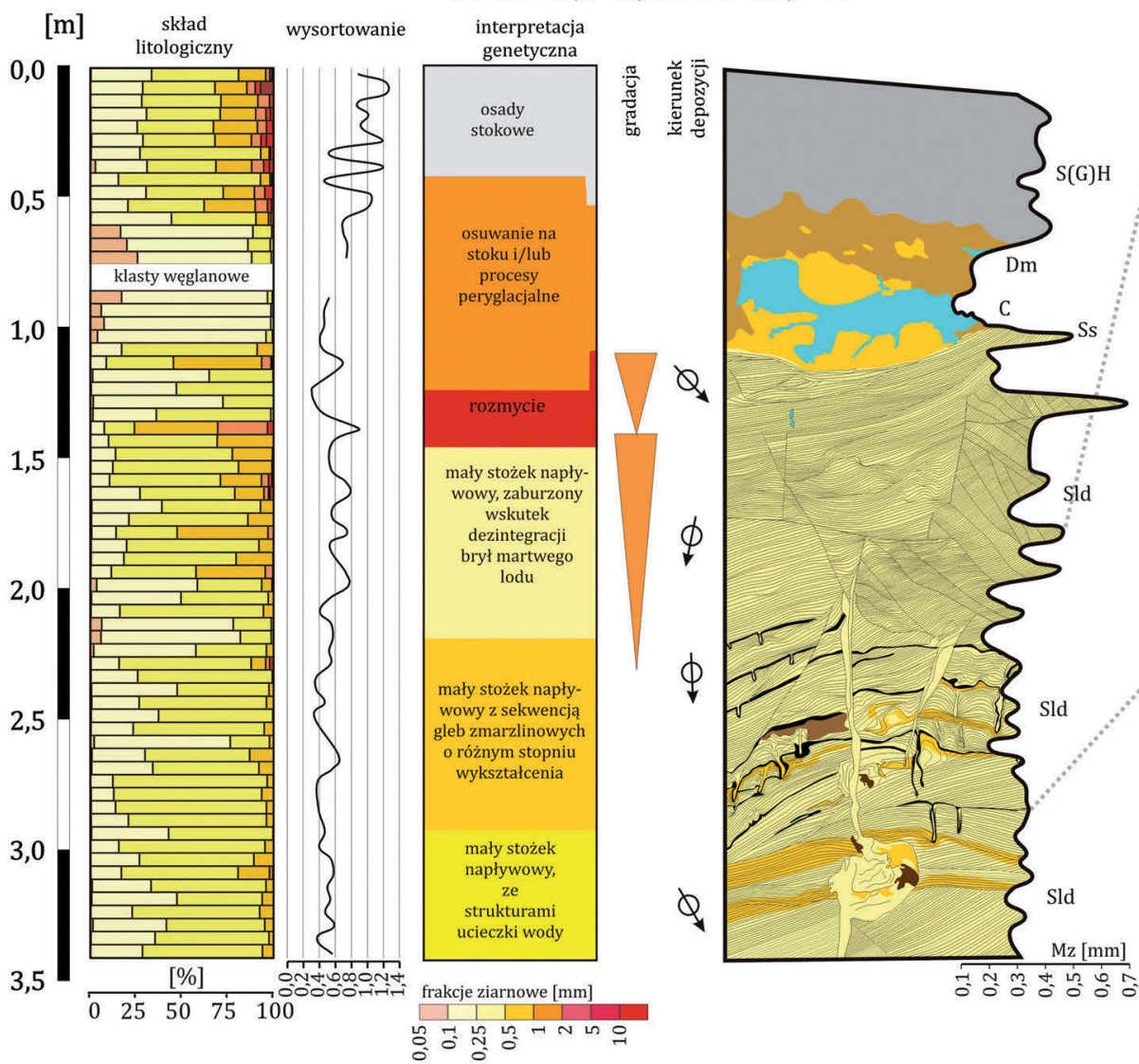

sekwencja gleb zmarzlinowych

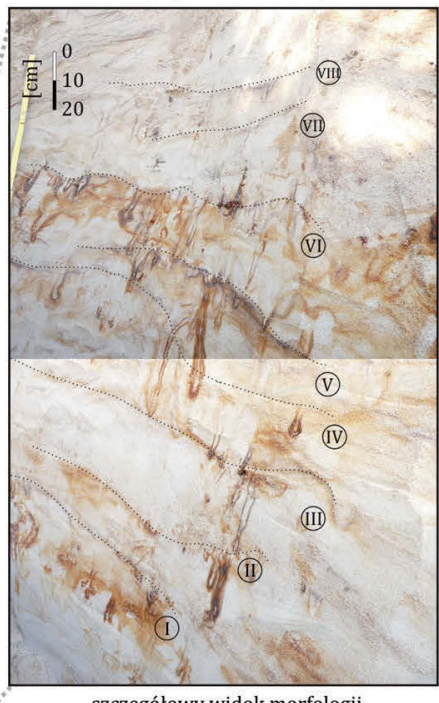

szczegółowy widok morfologil gleb zmarzlinowych

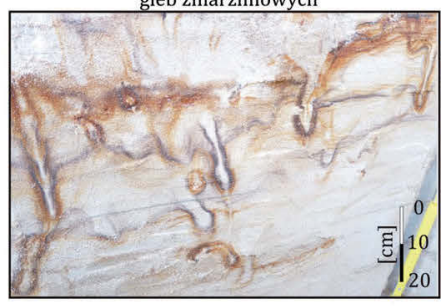

Ryc. 9. Stanowisko Czechowo 5. Osady stokowe ułożone na krawędzi bryły lodowej z serią gleb peryglacjalnych oraz strukturami ucieczki wody

Fig 9. Site Czechowo 5. Late Glacial colluvial sediments deposited on the edge of an ice block with a series of periglacial soils and water escape structures 
Ss - piaski w rozmyciach dużej skali. Stwierdzone zostały na stanowisku Czechowo 5 (ryc. 9). Litofacja Ss złożona jest $\mathrm{z}$ piasków drobnoziarnistych i średnioziarnistych o bardzo dobrym i dobrym wysortowaniu. Głębokość rozmycia można oszacować na 0,5 m, a szerokość na 2-3 m. Na granicy z niżej leżącymi osadami nie zaznacza się grubienie ziarna.

Interpretacja: mimo względnie drobnoziarnistego charakteru dla litofacji Ss wskazuje ona na szybki przepływ wody w górnym reżimie przepływu (Simons i in. 1965). Brak grubienia ziarna w spągu litofacji świadczy o kanałowym wcięciu w identyczne litologicznie osady podścielające.

Sw(a) - piaski o warstwowaniu falistym (antydiuny) (ryc. 13, stanowisko Czechowo 9). Składają się z mieszaniny piasku średnioziarnistego (10-20\%), gruboziarnistego (30-40\%), drobnoziarnistego (ok. 5\%) i domieszki żwiru drobnoziarnistego (ok. 5\%). Wysortowanie osadów litofacji Sw(a) jest słabe. Tworzą one zestaw o miąższości zaledwie $10 \mathrm{~cm}$, w wielu miejscach przechodząc obocznie w warstwowanie horyzontalne. Amplituda lamin falistych wynosi około $15 \mathrm{~cm}$, zaś długość dochodzi do 1 m. Fale te są zatem bardzo spłaszczone. Układ lamin jest symetryczny, nie zauważa się wyraźnego przemieszczania wierzchołka ani siodła fali.

Interpretacja: kontekst geologiczny opisywanej litofacji wyklucza genezę w wyniku działania falowania brzegowego. Zróżnicowany charakter uziarnienia i słabe wysortowanie wskazuje na górny reżim przepływu, najprawdopodobniej fazę antywydmową, z dużą energią przepływu wody. Symetryczny charakter lamin bez przemieszczania grzbietów fali może wskazywać na stacjonarny charakter antydiun, diagnostyczny dla nadkrytycznego reżimu przepływu (Cartigny i in. 2014).

Sp(id) - piaski warstwowane przekątnie płasko z deformacjami wewnątrzwarstwowymi. Stwierdzone zostały na stanowisku Czechowo 4 (ryc. 8). W 90\% litofacja ta składa się z piasku średnio- i gruboziarnistego. Około 2-3\% stanowią ziarna żwiru drobnoziarnistego, a resztę piasek średnio- i drobnoziarnisty. Wysortowanie osadów litofacji Sp(id) jest raczej słabe. Miąższość zdeformowanej wewnętrznie litofacji wynosi około $20 \mathrm{~cm}$ (ryc. 8, środkowa fotografia).

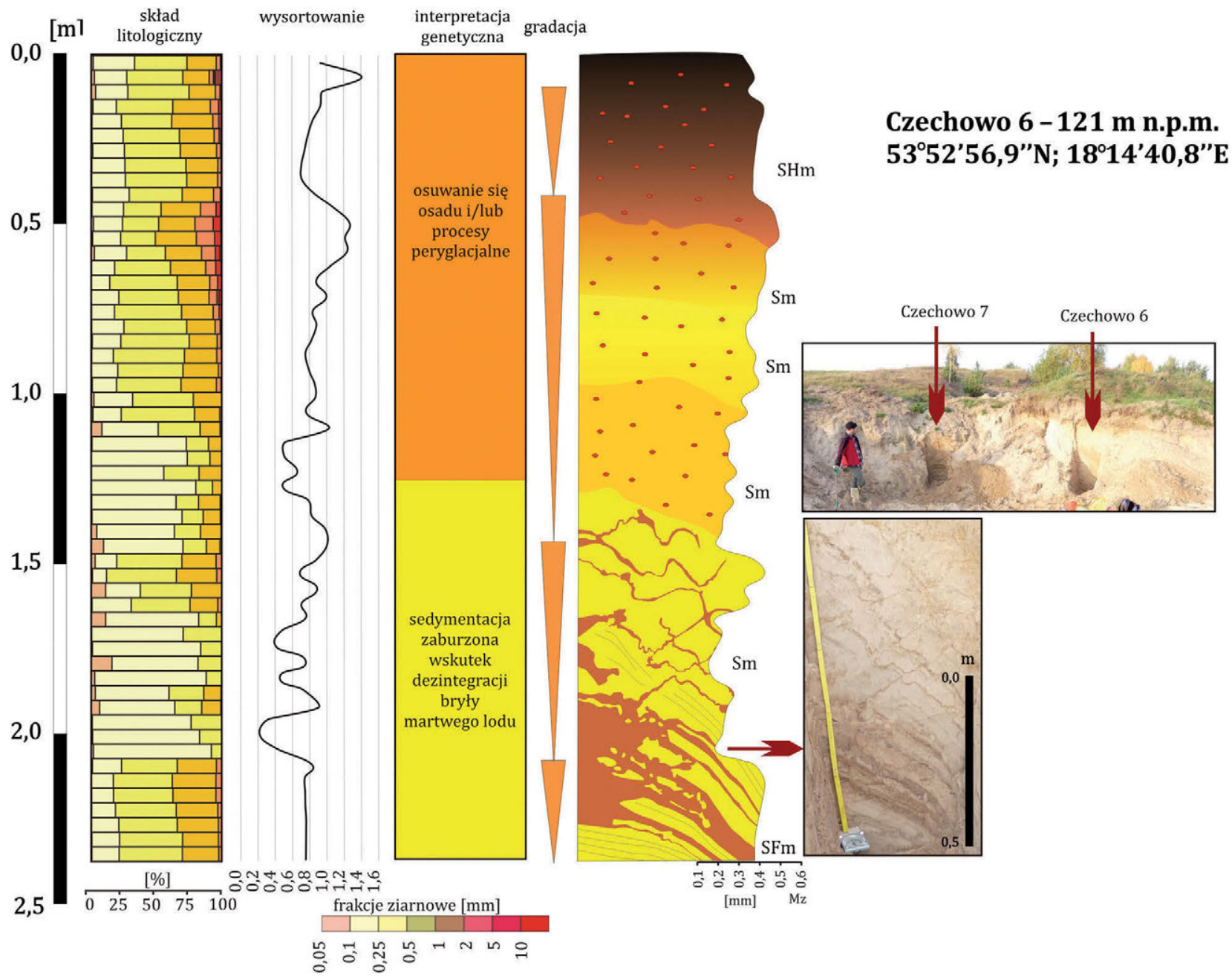

Ryc. 10. Stanowisko Czechowo 6. Osady glacjofluwialne i peryglacjalne zaburzone na bezpośrednim kontakcie z jedną z brył martwego lodu

Fig. 10. Site Czechowo 6. Glacifluvial and periglacial sediments disturbed at the contact with one of the dead ice blocks 
Interpretacja: litofacja $\mathrm{Sp}(\mathrm{id})$ jest charakterystyczna dla niewielkich odsypów poprzecznych lub diun o prostych grzbietach, których osady podlegały syn- i metadepozycyjnej deformacji wewnątrzławicowej (Allen, Banks 1972, Owen 1996, Pisarska-Jamroży, Weckwerth 2013).

Sh - piaski warstwowane horyzontalnie. Stwierdzone zostały na stanowisku Czechowo 3 (ryc. 7). Ich odmianą są litofacja SGh (ryc. 13, stanowisko Czechowo 9), która tworzą piaski i żwiry warstwowane horyzontalnie oraz litofacja $\mathrm{S}(\mathrm{G}) \mathrm{h}$ zbudowana z piasków z domieszką żwirów o warstwowaniu horyzontalnym (ryc. 7, stanowisko Czechowo 3, ryc. 13, stanowisko Czechowo 9).

Interpretacja: litofacje $\mathrm{Sh}, \mathrm{SGh}$ oraz $\mathrm{S}(\mathrm{G}) \mathrm{h}$ odpowiadają warunkom sedymentacji górnego płaskiego dna (Simons i in. 1965).

Dm - diamikton masywny z przeważnie rozproszonym szkieletem ziarnowym. Stwierdzony został na stanowiskach Czechowo 1 (ryc. 5) i 5 (ryc. 9). Ma on bardzo zróżnicowany skład granulometryczny. Zawartość iłu i mułków w masie osadu jest zmienna i wynosi od kilku do blisko $80 \%$. Cechą wspólną jest spojenie ziaren piasku i żwiru materiałem mułkowo-ilastym bądź wręcz rozpro- szenie materiału grubszego $\mathrm{w}$ mułkowo-ilastej matriks. Miąższość litofacji wynosi do $70 \mathrm{~cm}$.

Interpretacja: diamiktony Dm są efektem spływów materiału morenowego z wytapiających się brył martwego lodu (Syverson 1998).

\section{Osady glacjolimniczne}

Osady glacjolimniczne zostały rozpoznane na stanowiskach Czechowo 2 (ryc. 6), 7 (ryc. 11), 8 (ryc. 12), 10 i 11 (ryc. 14). Ponadto zidentyfikowano je również w wierceniach przedstawionych na przekroju geologicznym nr II (ryc. 15 - A). Osady glacilimniczne składają się z mułków i iłów, a początek ich depozycji miał miejsce w czasie, kiedy misa jeziora konserwowana była martwym lodem, a warunki klimatyczne nie pozwalały na rozwój roślinności.

SFrt - heterolityczne rytmity piaszczysto-mułkowe i piaszczysto-ilaste. Stwierdzone zostały na stanowisku Czechowo 7 (ryc. 11). W profilu tym litofacja ta osiąga około $2 \mathrm{~m}$ miąższości. Składa się z lamin piaszczystych (głównie piasek średnioziarnisty i gruboziarnisty) i lamin piaszczysto-ilastych lub piaszczysto-mułkowych ze

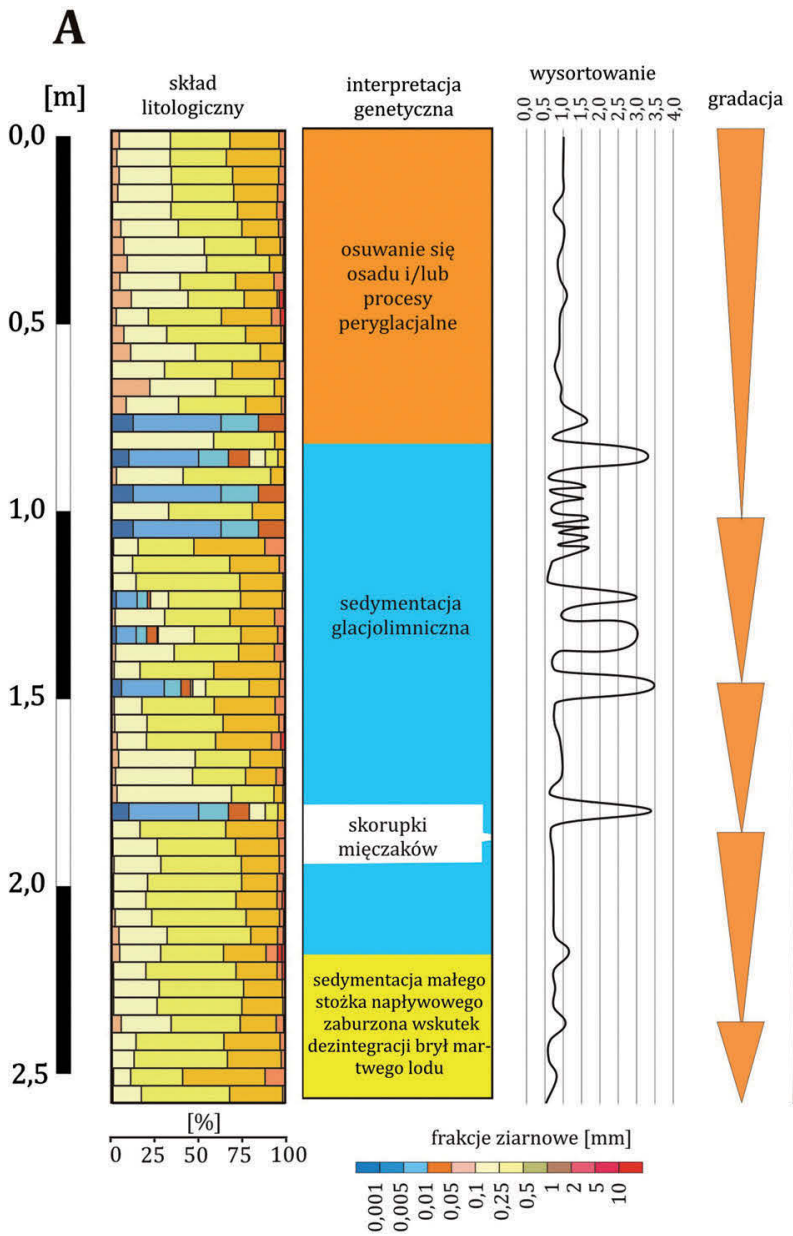

Czechowo 7-120 m n.p.m. $53^{\circ} 52^{\prime} 57,0^{\prime \prime} \mathrm{N} ; 1^{\circ} 14^{\prime} 40,6^{\prime \prime} \mathrm{E}$

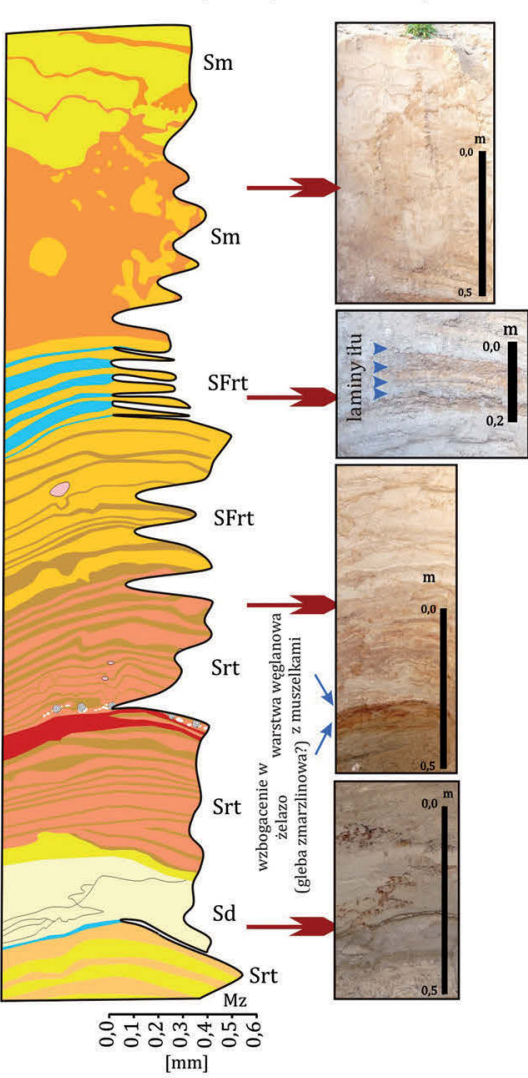

B

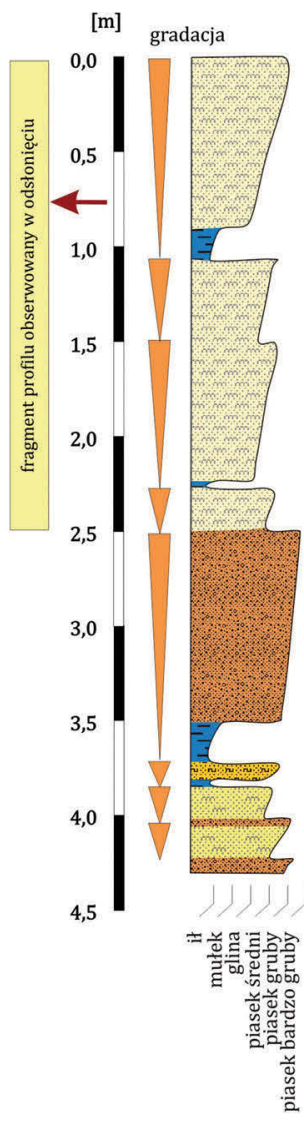

Ryc. 11. Stanowisko Czechowo 7. Rytmicznie akumulowane osady glacjolimniczne

A - struktury wewnętrzne i uziarnienie, B - profil litologiczny wiercenia

Fig. 11. Site Czechowo 7. Rhythmically accumulated glaciolimnic sediments A - internal structures and grain-size distribution, B - lithological log of the borehole 
zmienną zawartością iłu, między 15 a 75\%. Zestawy rytmitów tworzą cykle frakcjonowane odwrócone o miąższości $40-50 \mathrm{~cm}$. W niektórych cyklach występują klasty żwirowe (ang. dropstone). W stropie jednego $\mathrm{z}$ nich zalega kilkumilimetrowej miąższości przewarstwienie węglanowe $\mathrm{z}$ drobnymi muszelkami. Wysortowanie jest bardzo słabe.

Interpretacja: litofacja SFrt powstała najprawdopodobniej $\mathrm{w}$ otwartym zbiorniku wodnym pozostającym pod silnym wpływem procesów ablacji w jego otoczeniu (Syverson 1998). Dostawa materiału musiała być duża ze względu na brak zaznaczonego procesu wysortowania. Głównymi czynnikami depozycyjnymi były prawdopodobnie gęste prądy zawiesinowe gwałtownie wytracające energię w obrębie zbiornika wodnego, najprawdopodobniej wskutek zmniejszenia nachylenia stoku.

SFm - piaski drobnoziarniste i mułki, masywne. Stwierdzone zostały na stanowisku Czechowo 2 (ryc. 6).
Łącznie osady te cechują się miąższością zaledwie $0,5 \mathrm{~m}$, ale mają istotne znaczenie interpretacyjne, bowiem wskazują, że w końcowej fazie sedymentacja glacjofluwialna przerywana była epizodami sedymentacji glacjolimnicznej. W profilu Czechowo 7, włączając uzupełniające wiercenie, stwierdzono co najmniej cztery takie epizody (ryc. 11). Przewarstwienia SFm miały tam miąższość od kilku do $20 \mathrm{~cm}$. Między nimi występowały pakiety osadów piaszczystych z odwróconym uziarnieniem gradacyjnym i o miąższości $1-1,5 \mathrm{~m}$. Osady te składają się głównie z piasku drobnoziarnistego (70-80\% masy osadu) z domieszką mułku piaszczystego (20-30\%). Indywidualne ławice mają od kilku do kilkunastu centymetrów miąższości. Istotne jest występowanie obleczonych klastów żwirów o średnicy do $10 \mathrm{~cm}$.

Interpretacja: litofacja SFm związana jest z depozycją zawiesinową w spokojnym zbiorniku poniżej podstawy falowania. Obecność dużych klastów żwirowych

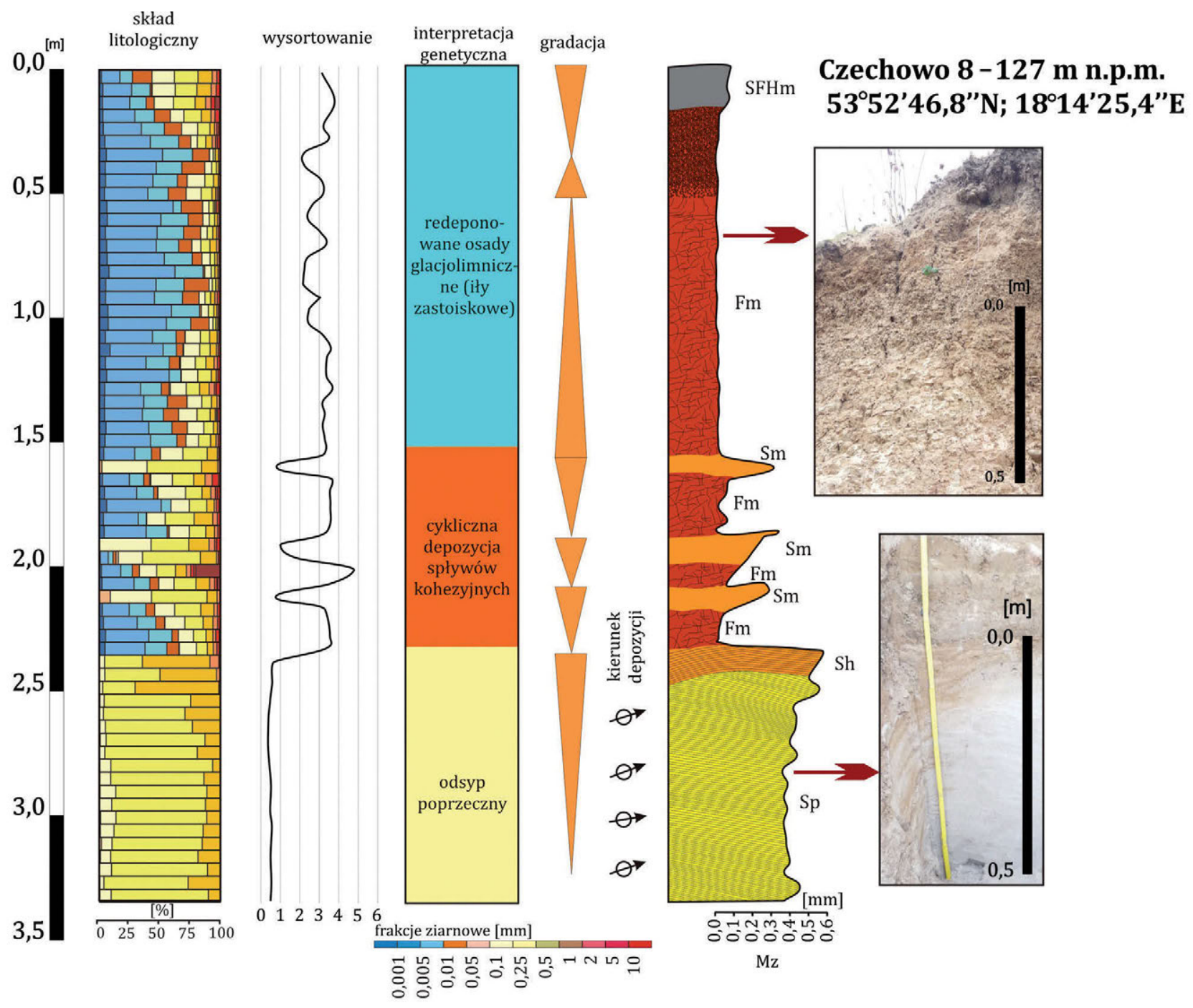

Ryc. 12. Stanowisko Czechowo 8. Redeponowane osady glacjolimniczne lokalnego zastoiska na granicy bryły lodowej i wysoczyzny morenowej

Fig. 12. Site Czechowo 8. Redeposited glaciolimnic sediments of a local marginal lake at the contact of the dead ice with the morainic plateau 
świadczy o dostawie przymarzniętego materiału wraz z krami lodowymi i/lub górami lodowymi z innych partii zbiornika (Kempema i in. 2001).

Fm - mułki i ily masywne. Stwierdzone zostały na stanowisku Czechowo 8 (ryc. 12). Składają się głównie $\mathrm{z}$ brązowego iłu gruboziarnistego i drobnoziarnistego, który stanowi z reguły ponad $50 \%$ masy osadu. Domieszki frakcji bardziej gruboziarnistej (mułki, piaski i żwiry) stanowią łącznie od 10 do $50 \%$. W iłach występuje mała, ale istotna dla interpretacji genetycznej domieszka żwiru (1-2\% masy osadu). Całkowita miąższość tej litofacji osiąga około 2,5 m. W części spągowej znajdują się przewarstwienia piasku masywnego o miąższości do 10 $\mathrm{cm}$. Stwierdzono także charakterystyczne spękania pryzmatyczne i kostkowe. Wysortowanie osadu jest słabe, ale nieistotne $\mathrm{z}$ punktu widzenia genezy, bowiem nie uwzględnia flokulacji cząstek ilastych w czasie sedymentacji (Eisma 1993).

Interpretacja: kontekst geologiczny tej litofacji wskazuje, że są to redeponowane mułki i iły zastoiskowe pierwotnie akumulowane w spokojnym zbiorniku sedymentacyjnym. Domieszka piaszczysta i żwirowa może pochodzić z trzech źródeł. Pierwszym jest depozycja na lodzie pokrywającym tymczasowo, w okresie zimowym, powierzchnię basenu sedymentacyjnego. Drugim jest możliwość inkorporacji piasku do ilastej matriks w czasie przesuwania się po piaszczystym podłożu. Część materiału, zwłaszcza żwirowego, mogła także przywędrować przymarznięta wraz z krami lodowymi, odrywającymi się od brzegów zbiornika. Fleksury obserwowane na przekroju II wskazują na rozpowszechnioną subsydencję wskutek stopniowego wytapiania brył martwego lodu podpierających te osady (ryc. 15A).

\section{Osady limniczne i utwory telmatyczne}

Osady limniczne i utwory telmatyczne rozpoznano w ponad 120 wierceniach (lokalizacje poszczególnych wierceń na ryc. 4). W niniejszym artykule przedstawione są tylko cztery z nich (ryc. 14, 15). Maksymalna stwierdzona miąższość omawianych osadów osiągnęła $12 \mathrm{~m}$. Początek ich akumulacji miał miejsce na przełomie starszego dryasu i allerødu (Błaszkiewicz 2005a) i zaznaczył się krótkotrwałym epizodem sedentacji „,torfu bazalnego" (ryc. 16). Występuje on zazwyczaj w postaci pojedynczej, cienkiej warstewki o miąższości przeważnie $2-3 \mathrm{~cm}$. Lokalnie analizowana warstwa organiczna przedzielona jest warstewką piasku o miąższości do kilku centymetrów, wskazując wyraźnie na wieloetapowość rozwoju torfowisk ponad pogrzebanymi bryłami martwego lodu. Warstewka ta wy-

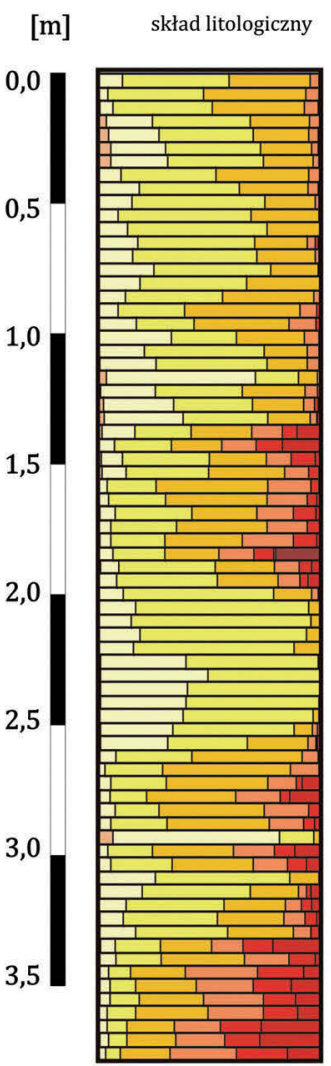

$[\%]$ wysortowanie interpretacja genetyczna gradacja
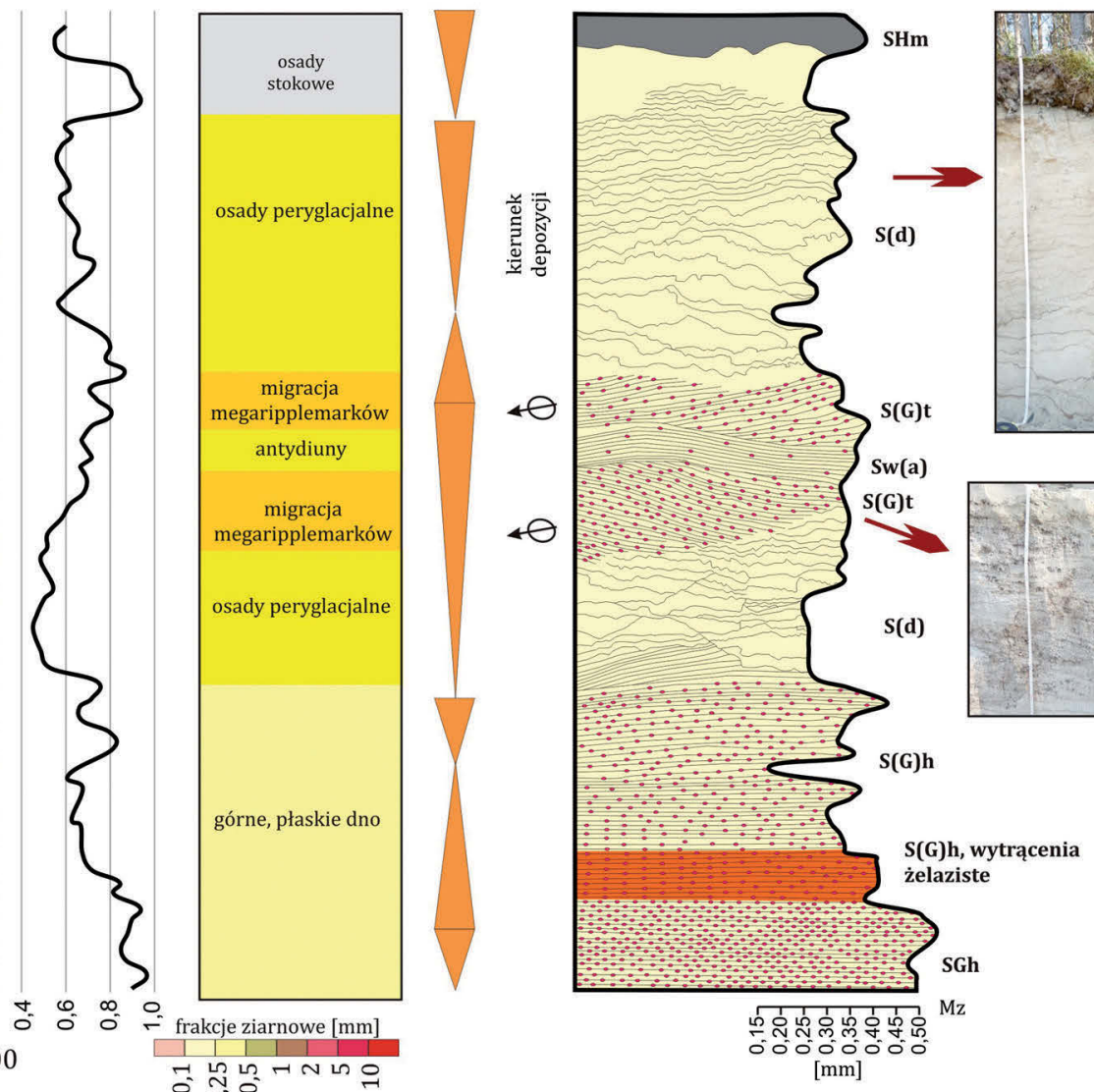

Czechowo 9-112,5 m n.p.m. 53 ${ }^{\circ} 52^{\prime} 57,3^{\prime \prime} \mathrm{N}$; 1813'52,5'E

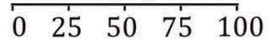

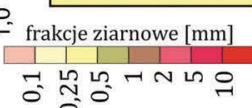


stępuje często w postaci resztek słabo rozłożonej ściółki roślinności tundrowej albo zmieszanych szczątków roślinnych, redeponowanych wskutek późniejszego wytopienia pogrzebanych brył martwego lodu. W analizowanym obszarze składa się ona ze szczątków takich roślin, jak: brzoza karłowata (Betula nana L.), mącznica lekarska (Arctostaphylos uva-ursi L. Spreng.), bażyna czarna (Empetrum cf. nigrum L.), dębik ośmiopłatkowy (Dryas octopetala L.), rokitnik zwyczajny (Hippophaë rhamnoides L.) i sosna zwyczajna (Pinus sylvestris L.).

Typowo limniczna faza rozwoju jeziora rozpoczęła się na początku allerødu depozycją białej gytii węglanowej o miąższości kilkudziesięciu centymetrów, która w części spągowej wykazuje laminację. Gytia ta, podobnie jak

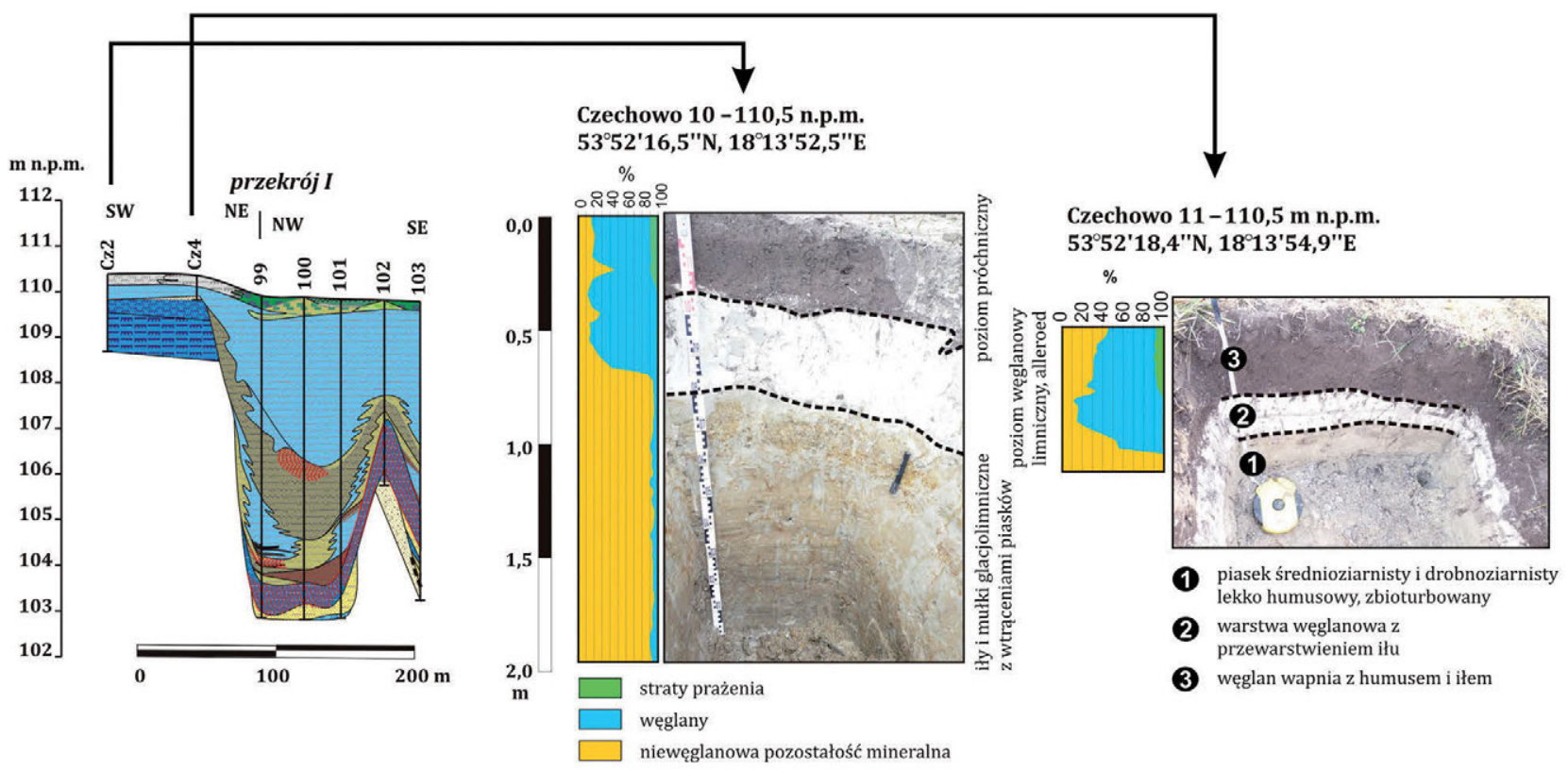

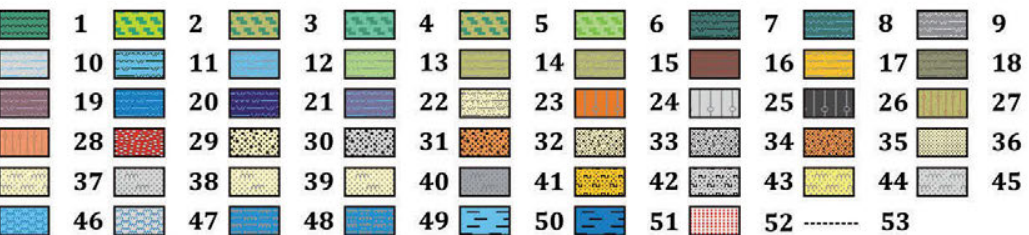

Ryc. 14. Stanowiska Czechowo 10 i 11 . Gytia (allerød lub nieco starsza) na ilastych osadach glacjolimnicznych

1 - mursz, 2 - torf turzycowy, 3 - torf turzycowo-trzcinowy, 4 - torf trzcinowy, 5 - torf mszysty, 6 - gytia organiczna, grubodetrytusowa, 7 - gytia organiczna, grubodetrytusowo-węglanowa, 8 - gytia organiczna, drobnodetrytusowa, 9 - gytia organiczna, grubodetrytusowo-węglanowa, 10 - gytia organiczna, drobnodetrytusowo-węglanowa, 11 - gytia węglanowa, 12 - gytia węglanowa z piaskiem, 13 - gytia węglanowo-detrytusowa, 14 - gytia węglanowo-glonowa, 15 - gytia węglanowo-glonowa z piaskiem, 16 - gytia glonowa, 17 - gytia glonowo-detrytusowa, 18 - gytia glonowo-węglanowa, 19 - gytia glonowo(-ilasto)-mułkowa, 20 - gytia węglanowo(-ilasta)-mułkowa, 21 - gytia mułkowo(-ilasta)-węglanowa, 22 - gytia mułkowo(-ilasto)-glonowa, 23 - piasek z gytią, 24 - glina ilasta, 25 - glina ilasta z humusem, 26 - glina ilasta, silnie humusowa, 27 - glina ilasta, silnie węglanowa, 28 - glina piaszczysta, 29 - żwiry, 30 - piasek różnoziarnisty, przemyty, 31 - piasek różnoziarnisty z humusem, 32 - piasek różnoziarnisty, gliniasty, 33 - piasek różnoziarnisty z pojedynczymi żwirami, przemyty, 34 - piasek różnoziarnisty z pojedynczymi żwirami i humusem, 35 - piasek różnoziarnisty z pojedynczymi żwirami, gliniasty, 36 - piasek średni, przemyty, 37 - piasek średni, mułkowaty, 38 - piasek średni z humusem, 39 - piasek średni, nieco mułkowaty, 40 - piasek średni, nieco mułkowaty z humusem, 41 - piasek średni, nieco mułkowaty, silnie humusowy, 42 - piasek średni, gliniasty, 43 - piasek średni, gliniasty, humusowy, 44 - piasek drobny, mułkowaty, 45 - piasek drobny, mułkowaty z humusem, 46 - mułek piaszczysty, 47 - mułek piaszczysty z humusem, 48 - mułek ilasty, 49 - mułek ilasty z piaskiem, 50 - ił węglanowy, 51 -ił, 52 - laminacja lub drobne warstwowanie, 53 - detrytus roślinny

Fig. 14. Sites Czechowo 10 and 11. Gyttja (Allerød or slightly older) over the clayey glaciolimnic sediments

1 - boggy soil, 2 - sedge peat, 3 - sedge-reed peat, 4 - reed peat, 5 - moss peat, 6 - coarse detritus, organic gyttja, 7 - coarse detritus - calcareous organic gyttja, 8 - fine detritus, organic gyttja, 9 - coarse detritus - calcareous organic gyttja, 10 - fine detritus-calcareous organic gyttja, 11 - carbonaceous gyttja, 12 - carbonaceous gyttja with sand, 13 - carbonaceous-detritus gyttja, 14 - calcareous-algal gyttja, 15 - calcareous-algal gyttja with sand, 16 - algal gyttja, 17 - algal detritus gyttja, 18 - algal-calcareous gyttja, 19 - algal(-clayey)-silty gyttja, 20 - carbonaceous(-clayey)-silty gyttja, 21 - silty(-clayey)-carbonaceous gyttja, 22 - silty(-clayey)-algal gyttja, 23 - sand with gyttja, 24 - clayey till, 25 - clayey till with humus, 26 - clayey till, strongly humic, 27 - clayey till, strongly carbonaceous, 28 - sandy till, 29 - gravels, 30 - poorly sorted sand, clear, 31 - poorly sorted sand with humus, 32 - poorly sorted sand, diamictic, 33 - poorly sorted sand with individual gravels, clear, 34 - poorly sorted sand with individual gravels and humus, 35 - poorly sorted sand with individual gravels, diamictic, 36 - medium sand, clear, 37 - medium silty, sand, 38 - medium sand with humus, 39 - medium sand, slightly silty, 40 - medium sand, slightly silty with humus, 41 - medium sand, slightly silty, strongly humic, 42 - medium diamictic sand, 43 - medium, diamictic sand with humus, 44 - fine, silty sand, 45 - fine silty sand with humus, 46 - coarse silt, 47 - coarse silt with humus, 48 - fine silt, 49 - fine silt with sand, 50 - carbonaceous clay, 51 - clay, 52 - lamination or fine stratification, 53 - plant detritus 
„torf bazalny”, występuje także do 1,5 m ponad współczesnym poziomem jeziora, w wielu miejscach na osadach glacjolimnicznych (ryc. 14). Z tego względu uważa- na jest za ślad najwyższego poziomu wody po wytopieniu brył martwego lodu konserwujących misę jeziora (ryc. 4). W gytii tej, stwierdzonej w sąsiednim obniżeniu na połu-
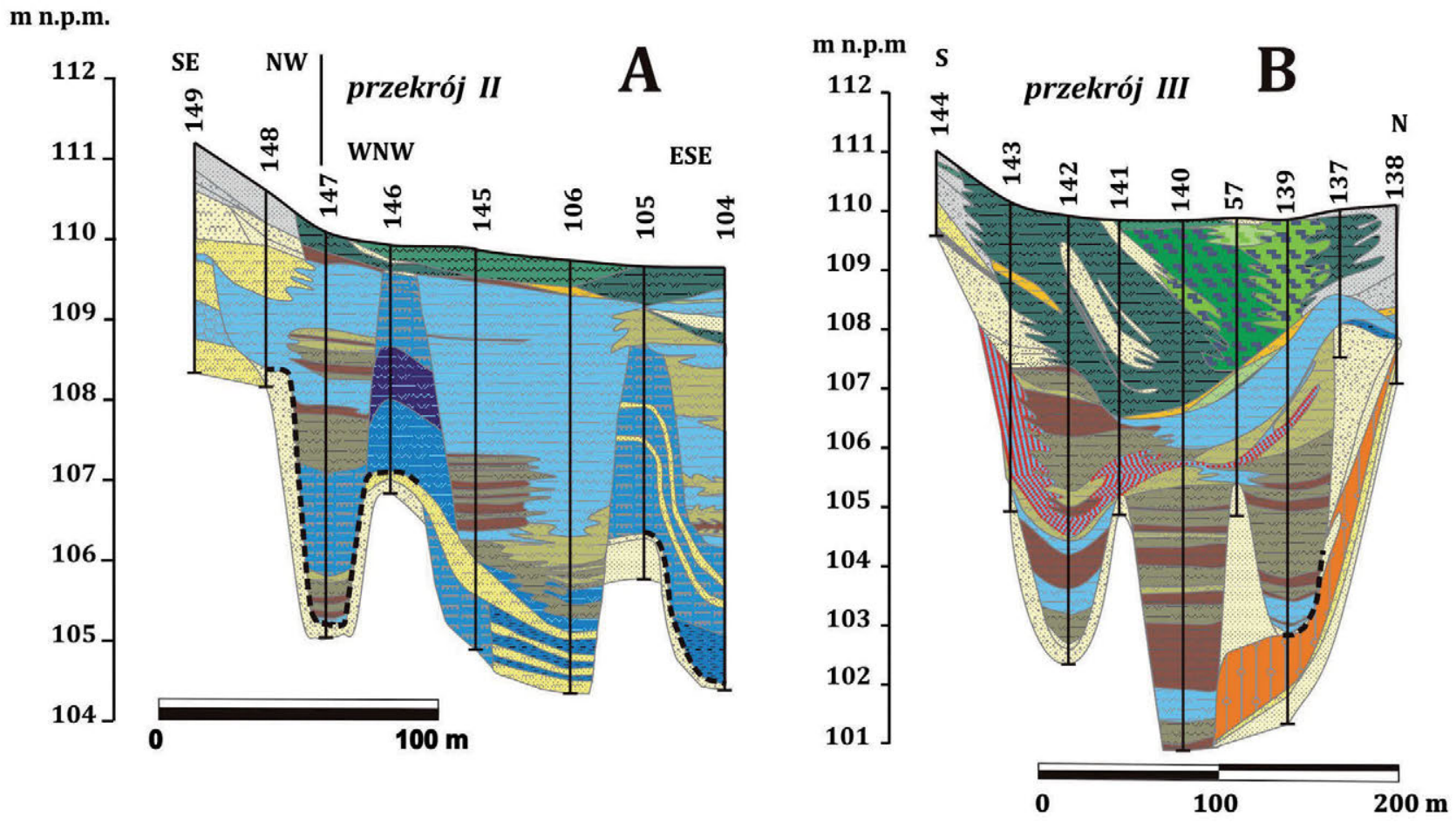

m n.p.m.

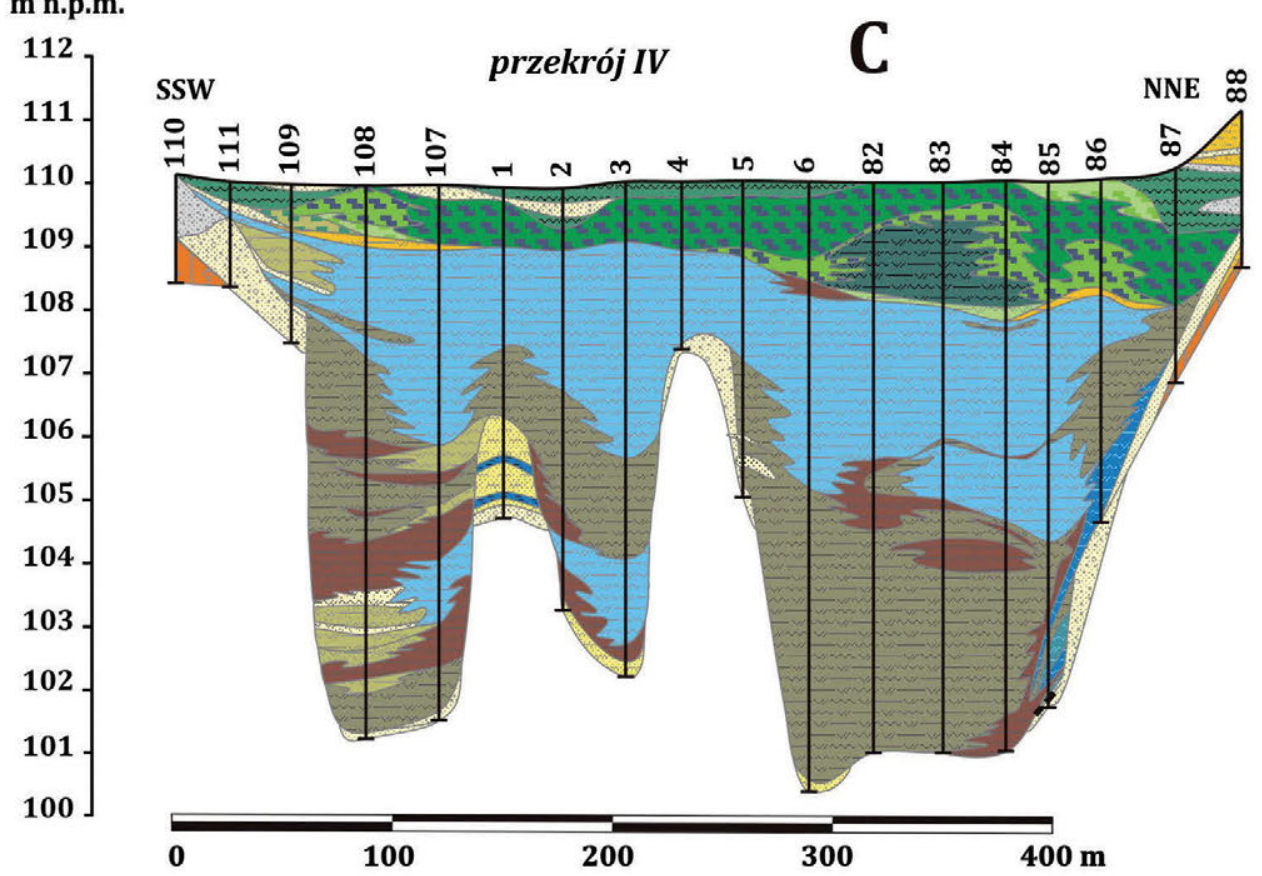

Ryc. 15. Przekroje geologiczne przez równinę biogeniczną w zachodnim i południowym otoczeniu Jeziora Czechowskiego A - przekrój II w południowej części jeziora obrazujący osady glacjolimniczne w spągu osadów limnicznych, B - przekrój III w zachodniej części zlądowiałej misy jeziora obrazujący zmienność litologiczną osadów limnicznych w obrębie głębokich i wąskich kociołków wytopiskowych, $\mathrm{C}$ - przekrój IV przez równinę biogeniczną na północny zachód od obecnej misy jeziornej obrazujący zróżnicowanie litologiczne osadów jeziornych w bardziej otwartych basenach sedymentacyjnych zlądowiałej części jeziora. Objaśnienia jak na rycinie 14.

Fig. 15. Geological cross-sections across the biogenic plains in the western and southern surrounding of Czechowskie Lake

A - cross-section II across the southern part of the lake illustrating glaciolimnic sediments at the base of the limnic sediments, B - cross- section III in the western, terrestrialised part of the lake depicting lithological variability of the limnic sediments within deep and narrow kettle holes, C - cross-section IV across the biogenic plain to the north-west from the actual lake depicting lithological variability of the lacustrine sediments in more open basin of the terrestrialised part of the lake. Explanations as in the Figure 14 
dniowy zachód od Jeziora Czechowskiego, w torfowisku zwanym Trzechowskim, znaleziono pojedyncze szkliwa wulkaniczne $\mathrm{z}$ wybuchu wulkanu Laacher See o wieku radiowęglowym $11065+/-20$ BP (12 934+/-165 cal. BP) (Wulf $\mathrm{i}$ in. 2013).

Dalsza ewolucja procesów sedymentacji osadów dennych, w ich spągowych częściach, polegała na depozycji gytii mineralnych lub organicznych, na które składają się odmiany: glonowa, glonowo-węglanowa, mułkowo-węglanowa, mułkowa, mułkowo(-ilasto)-glonowa i węglanowo-glonowa. Mniej więcej w połowie większości wykonanych profili osady te przechodzą w różową gytię węglanową. Różowe zabarwienie związane jest najprawdopodobniej z obecnością obumarłych glonów z grupy krasnorostów (Rhodophyta). Glony te zawierają karotenoidy oraz barwniki czerwony - fikoerytrynę i niebieski - fikocyjaninę. W zależności od kombinacji tych barwników glony te przybierają barwy czerwone, różowe, brązowe, brązowo-zielone lub brązowo-fioletowe (Podbielkowski 1985). W gytiach tych występują często cienkie przewarstwienia gytii glonowej, glonowo-węglanowej i węglanowo-glonowej. W strefie przybrzeżnej i w pobliżu dawnych wysp jeziornych są wzbogacone w niewysortowane piaski i żwiry, co wskazuje na działalność falowania i wynoszenie utworów mineralnych w głąb zbiornika.

Torfy stwierdzone w rejonie Jeziora Czechowskiego są zróżnicowane pod względem składu i miąższości. Ich maksymalna miąższość dochodzi do $2,5 \mathrm{~m}$ i jest silnie zależna od lokalnego usytuowania w zlądowiałej części misy jeziornej. Stwierdzono następujące gatunki torfu: turzycowy (dominujący), turzycowo-trzcinowy, trzcinowo-mszysty, turzycowo-mszysty i mszysty.

\section{Osady stokowe i peryglacjalne}

W odsłonięciach Czechowo 1 (ryc. 5), 2 (ryc. 6), 3 (ryc. 7), 4 (ryc. 8), 5 (ryc. 9), 6 (ryc. 10), 7 (ryc. 11) i 9 (ryc. 13) udokumentowano najprawdopodobniej późnoglacjalne osady stokowe i peryglacjalne. Tworzą one albo specyficzną litofację Sld - piasków o warstwowaniu małokątowym o zdeformowanym przebiegu lamin (ryc. 9), albo litofację Sm (ryc. 5-8) lub też litofację S(d) piasków o strukturze masywnej bądź o warstwowaniu zaburzonym, które są efektem oddziaływania warunków peryglacjalnych (ryc. 13).

Litofacja Sld zbudowana jest z piasków średnioziarnistych (70-90\% masy osadu) z domieszką piasku średnioziarnistego (10-30\%, rzadko do $80 \%$ ), piasku gruboziarnistego (2-10\%) i mułku piaszczystego (03\%) (ryc. 9). Całość wykazuje raczej dobre wysortowanie. Miąższość litofacji Sld wynosi co najmniej 2,5 m. Akcesorycznie stwierdzone zostały niewielkie wkładki materiału gliniastego. Warstwowanie w górnej części serii osadów stokowych jest zaburzone. W części środkowej stwierdzono serię ośmiu gleb peryglacjalnych o różnym stopniu rozwoju. Powtarzają się one w odstępie pionowym co $20 \mathrm{~cm}$. Zazwyczaj złożone są z liczącej kilka milimetrów warstewki humusu bądź nieco zhumifikowanego detrytusu roślinnego, podścielonego warstewką żelazistą o zmiennej miąższości wynoszącej przeważnie $2-3 \mathrm{~cm}$. W przebiegu tych gleb zaznaczają się liczne kieszenie pokorzeniowe o głębokości od kilku do $20 \mathrm{~cm}$. Kieszenie te wyraźnie pochylone są pod kątem około $30^{\circ} \mathrm{w}$ kierunku południowym. Całość przecięta jest dwoma generacjami struktur ucieczki wody. Starsza struktura jest dłuższa i osiaga minimum $1,5 \mathrm{~m}$. Składa się ona $\mathrm{z}$ wąskiego komina o średnicy około 5 $\mathrm{cm}$, zaś w jej dolnej części stwierdzono strukturę komory z zaburzonym przebiegiem warstw i pojedynczymi bryłami gliniastymi. Komora ta ma średnicę około 30 $\mathrm{cm}$. Druga, młodsza struktura ucieczkowa wody jest krótsza, liczy bowiem około $0,5 \mathrm{~m}$ długości i składa się wyłącznie z komina.

Interpretacja: struktura osadów omawianej litofacji wskazuje, że deponowana była ona wieloetapowo na nachylonej powierzchni stoku. Rozwój gleb zmarzlinowych miał miejsce w okresie przerw sedymentacyjnych o różnej długości czasu trwania, czemu odpowiada zmienny stopień rozwoju gleb. Litofacja Sld buduje stożek napływowy o długości kilkunastu metrów. Gleby zmarzlinowe świadczą o przemarzaniu osadów. Z kolei struktury ucieczki wody, a szczególnie komora, są związane zapewne $\mathrm{z}$ tymczasowym zatrzymaniem i uruchomieniem skoncentrowanego przepływu wody porowej. Tymczasowe przemarznięcie gruntu od powierzchni nie było głębokie, bo liczyło zaledwie około $1 \mathrm{~m}$. Być może związane jest to ze specyficzną lokalizacją analizowanego stanowiska bezpośrednio na krawędzi wytopiska.

S(d) - piaski o warstwowaniu zaburzonym deponowane w warunkach peryglacjalnych. Obserwowane były w odsłonięciu Czechowo 9 (ryc. 13). Składają się z piasków średnioziarnistych (50-80\%), gruboziarnistych (0-20\%) i drobnoziarnistych (10-20\%). Występuje też 3-4-procentowa domieszka żwiru drobnoziarnistego i średnioziarnistego. Wysortowanie osadów litofacji S(d) jest umiarkowane. Tworzą one zestawy o miąższości od $30 \mathrm{~cm}$ do około $1 \mathrm{~m}$. Warstwowanie to uległo deformacji, której efektem jest wykształcenie wśród lamin fałdów nieregularnych, zagięć, drobnych zagłębień. Miąższość pojedynczych warstewek o strukturze masywnej zmniejsza się od kilkunastu milimetrów w części spągowej litofacji do kilku milimetrów w części stropowej.

Interpretacja: deformacyjna struktura osadu i zazębianie się z serią glacjofluwialną wskazuje na duże prawdopodobieństwo kształtowania się litofacji $\mathrm{S}(\mathrm{d})$ w warunkach peryglacjalnych z częstym zamarzaniem i odmarzaniem wierzchniej powierzchni gruntu oraz grawitacyjnym przemieszczaniem płytko rozmarzniętego osadu w dół stoku, na którym następowała depozycja. Odmarzanie materiału było nierównomierne, stąd nieregularny przebieg poszczególnych warstw tej litofacji w profilu pionowym i poziomym (Jahn 1970).

Sm - piaski masywne. Stwierdzone zostały na stanowiskach Czechowo 1 (ryc. 5), 2 (ryc. 6), 3 (ryc. 7), 6 (ryc. 10), 7 (ryc. 11), 8 (ryc. 12). Składają się w przewadze z piasków drobno- i średnioziarnistych z lokalną domieszką pia- 

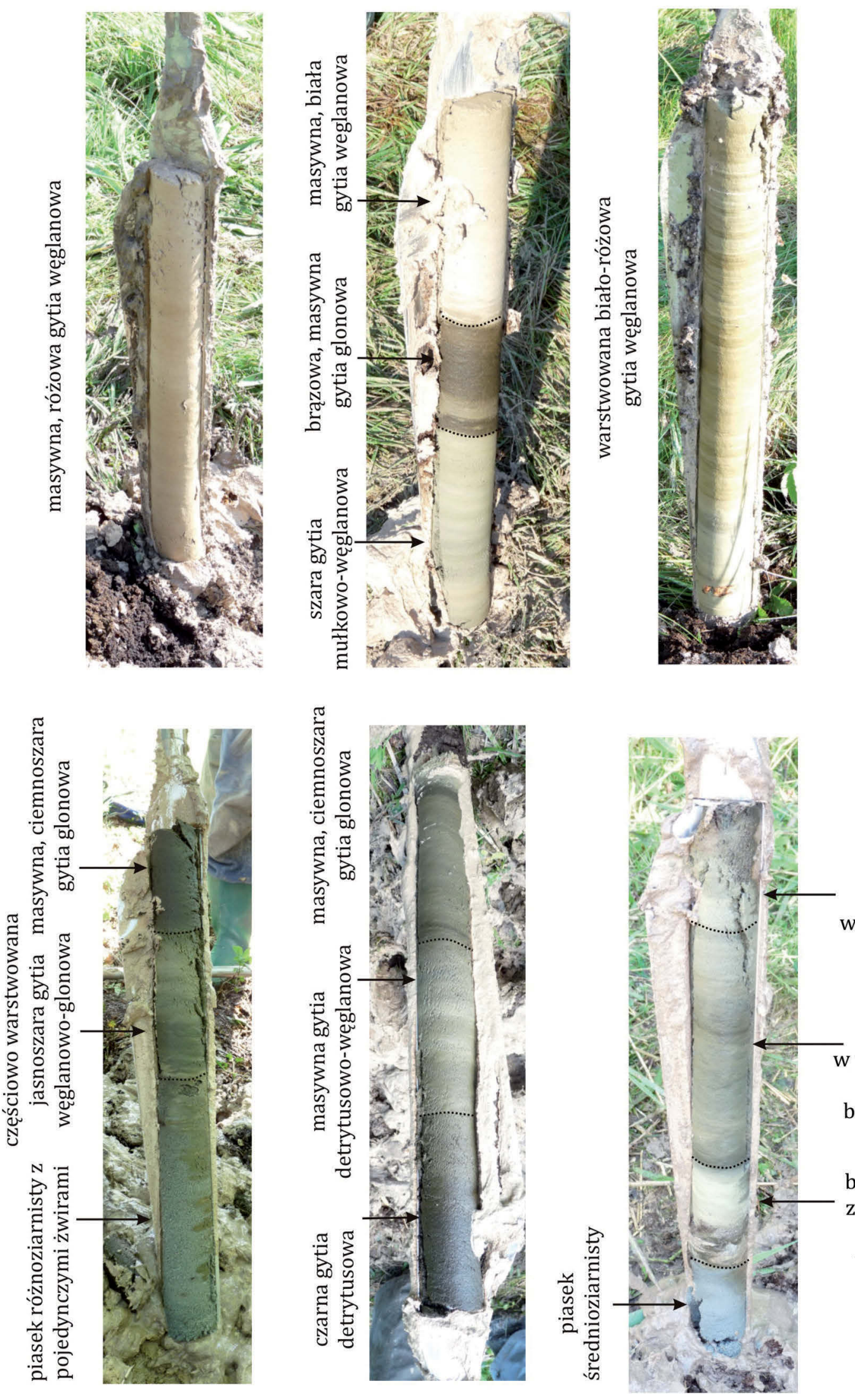

jasnoszara gytia węglanowo-glonowa

szara, masywna

gytia glonowa,

w większości głębszych wierceń nad

białą gytią allerødzką

biała gytia allerødzka, z reguły w większości głębszych wierceń, w spągu warstewka torfu bazalnego

Ryc. 16. Przykłady typowych struktur osadów organogenicznych w zlądowiałej części Jeziora Czechowskiego

Fig. 16. Examples of common organic sediment structures in the terrestrialised part of Czechowskie Lake 
sków gruboziarnistych. Są to osady bardzo słabo wysortowane i tworzą ławice o miąższości od około $20 \mathrm{~cm}$ do $1 \mathrm{~m}$.

Interpretacja: litofacje masywnych piasków (Sm) powstały prawdopodobnie $\mathrm{w}$ rezultacie osuwania się osadu po stoku lub w wyniku procesów peryglacjalnych powodujących zmiany pierwotnej jego struktury w efekcie wielokrotnego zamarzania i odmarzania.

\section{Wnioski - bryły martwego lodu jako dominujący czynnik morfogenezy misy jeziornej i depozycji osadów}

Rynna subglacjalna Jeziora Czechowskiego powstała w czasie recesji lądolodu na linię moren fazy pomorskiej. Bardzo zróżnicowana morfologia pierwotnego dna rynny, z licznymi przegłębieniami i progami, wskazuje, że forma ta związana jest z erozyjną działalnością wód roztopowych, znajdujących się pod ciśnieniem hydrostatycznym. Bezpośrednio po powstaniu rynna Jeziora Czechowskiego wypełniona była bryłami martwego lodu. W opinii autorów lód ten miał prawdopodobnie hydrogeniczny charakter, co mogło być związane ze zjawiskiem supercooling (Błaszkiewicz 2011). W trakcie recesji lądolodu ze strefy marginalnej związanej z fazą pomorską w otoczeniu rynny i ponad pogrzebanym w rynnie martwym lodem, sypany był sandr.
Analiza struktur sedymentacyjnych i uziarnienia osadów glacjofluwialnych wykazała, że warunki szybkiego, czasami nadkrytycznego przepływu, występowały z reguły w najbliższym otoczeniu największych wytopisk. Struktury związane z przepływem spokojnym, czasami nawet stagnacją wód, obserwowane są w częściach dystalnych sandru lub na granicy z wysoczyzną morenową.

Po zaprzestaniu przepływu proglacjalnego w południowej części Jeziora Czechowskiego funkcjonowało niewielkie jezioro zastoiskowe, w którym akumulowane były rytmity mułkowo-ilaste $\mathrm{z}$ dropstonami. Akumulacja tych osadów zachodziła w warunkach zalegania w rynnie brył martwego lodu.

Początek akumulacji jeziornej należy odnieść do allerødu. Wiercenia wykonane w obrębie dna współczesnej części misy Jeziora Czechowskiego wskazują, że akumulacja jeziorna nie była tutaj poprzedzona fazą torfowiskową. Praktycznie bezpośrednio na mineralnym podłożu pojawiają się laminowane gytie allerødzkie. Można przypuszczać zatem, że w centralnej części misy już na początku allerødu nastąpiło całkowite wytopienie się pogrzebanych brył martwego lodu. Z kolei w wielu wierceniach $\mathrm{w}$ torfowiskach przylegających do jeziora poniżej serii jeziornej stwierdzono obecność cienkiej allerødzkiej warstwy organicznej złożonej ze szczątków krzewiastych i zielnych roślin tundrowych.

Wyniki analizy wykonanych wierceń geologicznych pozwoliły na rekonstrukcję zróżnicowanej morfologii

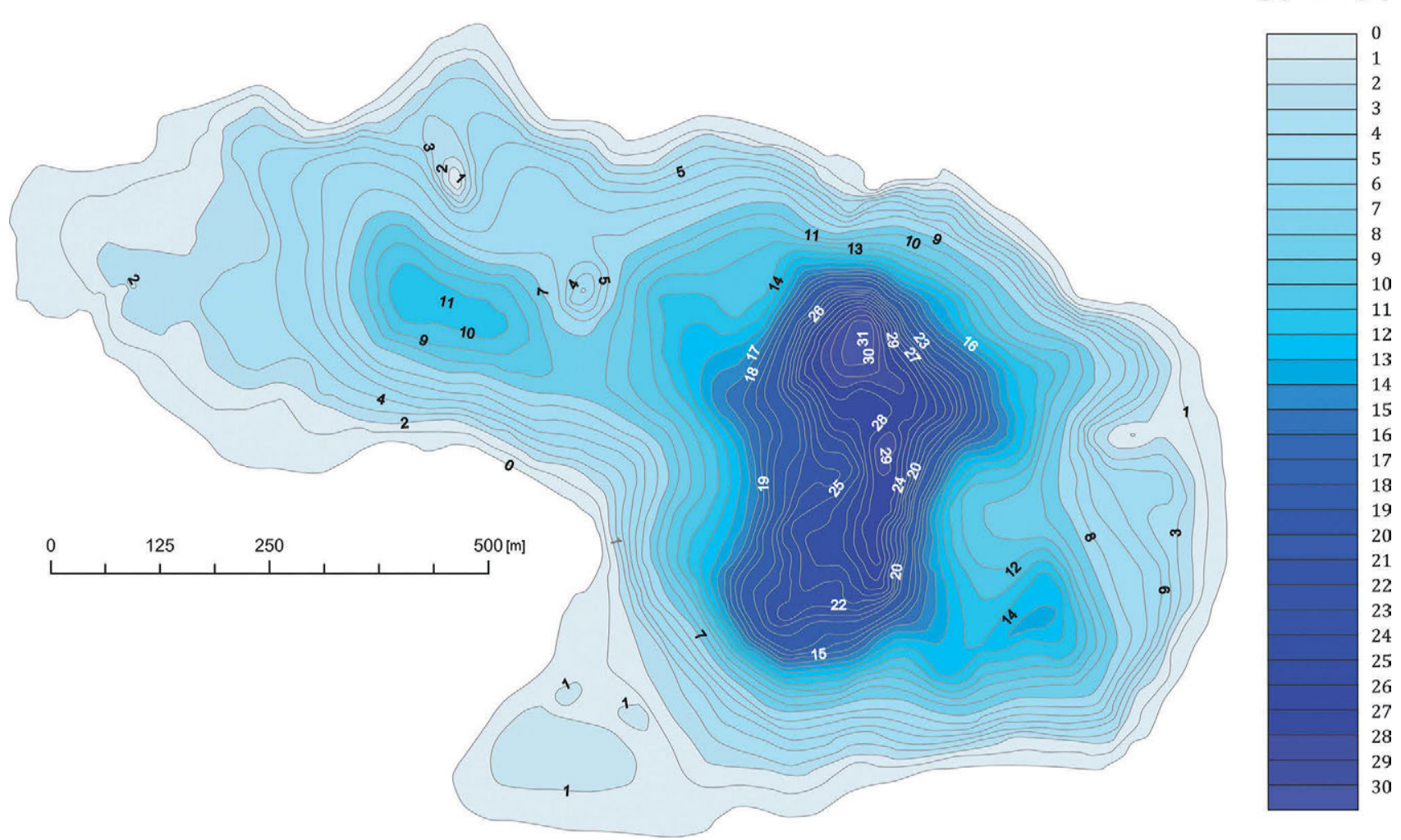

Ryc. 17. Plan batymetryczny Jeziora Czechowskiego

Fig. 17. Bathymetry of Czechowskie Lake 
pierwotnego dna rynny z licznymi kociołkami wytopiskowymi, położonymi zarówno w zlądowiałej części jeziora (ryc. 4), jak i w obecnej misie jeziornej (ryc. 17). Formy te mają zwykle ponad $10 \mathrm{~m}$ głębokości, a ich średnica na obszarze równin biogenicznych na zachód od jeziora wynosi przeciętnie kilkadziesiąt metrów. Rozdzielone są licznymi progami, które w głębszych partiach sprzyjały zachowaniu laminacji wskutek ograniczenia miksji i thumienia cyrkulacji gęstościowej w misie jeziornej. Ponadto podniesienie lustra wody poprzez zmianę podstawy falowania powodowało, że w niektórych, spągowych częściach profili pojawiają się trzy epizody laminacji gytii. Analiza przestrzennego rozmieszczenia osadów limnicznych wykazała zależność rodzaju sedymentacji od wielkości i stopnia izolacji każdego z lokalnych basenów sedymentacyjnych oraz aktualnego poziomu lustra wody. W małych, izolowanych zagłębieniach gytie są bardziej organiczne, z większą ilością detrytusu roślinnego, podczas gdy gytie w bardziej otwartych partiach dawnego jeziora mają więcej składnika węglanowego.

Torfy cechują się większą miąższością u północnych krańców zlądowiałej części misy jeziornej niż u krańców południowych. Związane to było prawdopodobnie z ograniczonym dostępem do ciepła i światła w ekspozycjach północnych, bardziej sprzyjających roślinom torfotwórczym.

Depozycja najstarszych deluwiów związana była najprawdopodobniej $\mathrm{z}$ chłodniejszymi okresami późnego glacjału. Została ona udokumentowana na stanowisku Czechowo 5, na którym stwierdzono słabo rozwinięte gleby peryglacjalne (ryc. 9). Datowania radiowęglowe wskazują wyraźnie na nasilenie depozycji deluwiów około 200 lat temu wskutek przejściowej deforestacji tego obszaru w czasie wojen napoleońskich.

\section{Podziękowania}

Prace badawcze prowadzone były przy wsparciu projektu NCN 2011/01/B/ST10/07367. [This study is a contribution to the Virtual Institute of Integrated Climate and Landscape Evolution (ICLEA) of the Helmholtz Association]. Nadleśnictwu Kaliska dziękujemy za pozwolenie na prowadzenie prac badawczych na terenie podległych lasów; Michałowi Fojutowskiemu, Michałowi Górnemu i Łukaszowi Jędrzejewskiemu - za pomoc przy pracach terenowych. Recenzentom i Redaktorom tomu dziękujemy za trud oceny i poprawy tekstu tego artykułu.

\section{Literatura}

Allen J.R.L., 1982. Sedimentary structures, Their character and physical basis. Vol. 2. Developments in sedimentology 30B. Elsevier Scientific, Oxford.

Allen J.R.L., Banks N.L., 1972. An interpretation and analysis of recumbent-folded deformed cross-bedding. Sedimentology 19: 257-283.

Babiński Z., 1992. Współczesne procesy korytowe dolnej Wisły. Prace Geograficzne 157.
Błaszkiewicz M., 2005a. Późnoglacjalna i wczesnoholoceńska ewolucja obniżeń jeziornych na Pojezierzu Kociewskim (wschodnia część Pomorza). Prace Geograficzne 201.

Błaszkiewicz M., 2005b. Szczegółowa mapa geologiczna Polski w skali 1:50 000, arkusz Stara Kiszewa. Państwowy Instytut Geologiczny, Warszawa.

Błaszkiewicz M., 2005c. Szczegółowa mapa geologiczna Polski w skali 1:50 000, arkusz Zblewo. Państwowy Instytut Geologiczny, Warszawa.

Błaszkiewicz M., 2006. Szczegółowa mapa geologiczna Polski w skali 1:50 000, arkusz Osiek. Państwowy Instytut Geologiczny, Warszawa.

Błaszkiewicz M., 2011. Timing of the final disappearance of permafrost in the Central European Lowland as reconstructed from the evolution of lakes in N Poland. Geological Quarterly 55(4): 361-374.

Bukowska-Jania E., 2003. Rola systemu lodowcowego w obiegu węglanu wapnia w środowisku przyrodniczym (na przykładzie Svalbardu i młodoglacjalnych obszarów Polski północno-zachodniej). Prace Uniwersytetu Śląskiego.

Cartigny M.J.B., Ventra D., Postma G., van den Berg J.H., 2014. Morphodynamics and sedimentary structures of bedforms under supercritical-flow conditions: New insights from flume experiments. Sedimentology 61: 712-748.

Eisma D., 1993. Suspended Matter in the Aquatic Environment. Springer Verlag, Berlin-Heidelberg-New York-London-Paris-TokyoHong Kong-Barcelona-Budapest.

Folk R.L., Ward W.C., 1957. Brazos River bar [Texas]; a study in the significance of grain size parameters. Journal of Sedimentary Research 27: 3-26.

Instrukcja opracowania i wydania Szczegółowej mapy geologicznej Polski w skali 1:50 000. 2004. Wyd. 2, uzupełnione. Państwowy Instytut Geologiczny, Warszawa.

Jahn A., 1970. Zagadnienia strefy peryglacjalnej. Państwowe Wydawnictwo Naukowe. Warszawa.

Kaiser K., Hilgers A., Schlaak N., Jankowski M., Kühn P., Bussemer S., Przegiętka K., 2009. Palaeopedological marker horizons in northern central Europe: Characteristics of Lateglacial Usselo and Finow soils. Boreas 38: 591-609.

Kempema E.W., Reimnitz E., Barnes P.W., 2001. Anchor-Ice Formation And Ice Rafting In Southwestern Lake Michigan. U.S.A. Journal of Sedimentary Research 71: 346-354.

Kozarski S., 1995. Deglacjacja północno-zachodniej Polski: warunki środowiska i transformacja geosystemu ( 20 ka-> $10 \mathrm{ka} \mathrm{BP})$. Dokumentacja Geograficzna 1: 1-82.

Marks L., 2002. Last Glacial Maximum in Poland. Quaternary Science Review 21: 103-110.

Miall A.D., 1996. The geology of fluvial deposits. Sedimentary facies, basin analysis and petroleum geology. John Wiley and Sons, Springer Verlag, Berlin-Heidelberg-New York.

Lang J., Winsemann J., 2013. Lateral and vertical facies relationships of bedforms deposited by aggrading supercritical flows: From cyclic steps to humpback dunes. Sedimentary Geology 296: 36-54.

Owen G., 1996. Experimental soft-sediment deformation: structures formed by the liquefaction of unconsolidated sands and some ancient examples. Sedimentology 43: 279-293.

Pisarska-Jamroży M., Weckwerth P., 2013. Soft-sediment deformation structures in a Pleistocene glaciolacustrine delta and their implications for the recognition of subenvironments in delta deposits. Sedimentology 60: 637-665.

Podbielkowski Z., 1985. Glony. Wydawnictwo Szkolne i Pedagogiczne, Warszawa.

Reineck H.E., Singh I.B., 1986. Depositional Sedimentary Environments. Springer Verlag, New York-Heidelberg-Berlin.

Simons D.B., Richardson E.V., Nordin C.F., 1965. Sedimentary Structures Generated by Flow in Alluvial Channels. Society of Economic Paleontologists and Mineralogists - Special Publication 12: 34-52.

Syverson K.M., 1998. Sediment record of short-lived ice-contact lakes, Burroughs Glacier, Alaska. Boreas 27(1): 44-54.

van Loon A.J., Błaszkiewicz M., Degórski M., 2012. The role of permafrost in shaping the Late Glacial relief of northern Poland. Netherlands Journal of Geosciences 91: 223-231.

Washburn A.L., 1979. Geocryology. A survey of periglacial processes and environments. Edward Arnold (Publishers) Ltd, London. 
Wulf S., Ott F., Słowiński M., Noryśkiewicz A.M., Dräger N., Martin-Puertas C., Czymzik M., Neugebauer I., Dulski P., Bourne A.J., Błaszkiewicz M., Brauer A., 2013. Tracing the Laacher See tephra in the varved sediment record of the Trzechowskie palaeolake in Central Northern Poland. Quaternary Science Reviews 76: 129-139.

Zieliński T., 1995. Kod litofacjalny i litogenetyczny - konstrukcja i zastosowanie. W: E. Mycielska-Dowgiałło, J. Rutkowski (red.), Badania osadów czwartorzędowych: wybrane metody i interpretacja. Wydział Geografii i Studiów Regionalnych Uniwersytetu Warszaw- skiego, Państwowy Instytut Geologiczny, Komisja Litologii i Genezy Osadów Czwartorzędowych Komitetu Badań Czwartorzędu PAN, AKAPIT-DTP, Warszawa: 220-235.

Zieliński T., 1988. Litofacjalna identyfikacja osadów rzecznych. W: E. Mycielska-Dowgiałło (red.), Struktury sedymentacyjne i postsedymentacyjne w osadach czwartorzędowych i ich wartość interpretacyjna. Wydział Geografii i Studiów Regionalnych Uniwersytetu Warszawskiego: 195-253. 